Article

\title{
Experimental Study on the Optimum Preparation of Bentonite-Steel Slag Composite Particles
}

\author{
Xinhui Zhan ${ }^{1, *}$ (D) , Liping Xiao ${ }^{2}$ and Bing Liang ${ }^{3}$ \\ 1 School of Mines, Liaoning Technical University, Fuxin 123000, China \\ 2 School of Civil Engineering, Liaoning Technical University, Fuxin 123000, China; youhebuke2018@126.com \\ 3 School of Mechanics and Engineering, Liaoning Technical University, Fuxin 123000, China; lbwqx@163.com \\ * Correspondence: zxhzhanxinhui@163.com
}

Received: 18 November 2019; Accepted: 14 December 2019; Published: 18 December 2019

check for updates

\begin{abstract}
Novel multifunctional adsorbent bentonite-steel slag composite particles (BSC) were developed for highly efficient and synergistic treatment of heavy metal ions in acid mine drainage (AMD). Single-factor experiments were performed to examine the influence of different parameters on the adsorption effect, alkalinity release quantity, and loss rate of the composite particles. Based on these results, an L9 $\left(4^{3}\right)$ orthogonal experiment was carried out, and the optimum levels and order of the factors were determined by range analysis. Finally, the optimum preparation process of the composite particles was determined: a bentonite-steel slag proportion of 5:5, $\mathrm{Na}_{2} \mathrm{CO}_{3}$ content of $5 \%$, aging time of $12 \mathrm{~h}$, calcination particle size of $2 \mathrm{~mm}$, calcination temperature of $500{ }^{\circ} \mathrm{C}$, and calcination time of $60 \mathrm{~min}$. The isothermal adsorption of optimum BSC fit well with Langmuir and Brunauer-Emmett-Teller (BET) isotherms $\left(R^{2} R^{2}>0.997\right)$. A synergistic adsorption-coagulation effect occurs, leading to the appearance of multiple layers locally on the surface of BSC, which satisfies the BET model. To understand the preparation mechanism of the BSC, bentonite, steel slag, uncalcined BSC, and the optimum BSC were characterized using scanning electron microscopy (SEM), Brunauer-Emmett-Teller (BET) surface area analysis, $X$-ray powder diffraction (XRD), and Fourier-transform infrared spectroscopy (FTIR). The results indicate that calcination led to an increase in the average pore radius, total pore volume, and specific surface area $\left(S_{B E T}\right)$ in the optimum BSC; numerous pores were present on its layered surface. Although the layer spacing increased after calcination, the structure of the dioctahedra remained unchanged. Exchangeable $\mathrm{Na}^{+}$, montmorillonite, and alkaline components were present between the optimum BSC layers. Water and impurities were removed after calcination. The BSC not only released an alkalinity-neutralising acid but also induced a synergistic adsorption-coagulation effect that removed heavy metal ions. It is an excellent multifunctional protective material for the mining environment, that can treat AMD-containing heavy metal ions.
\end{abstract}

Keywords: acid mine drainage (AMD); adsorption-coagulation; heavy metal ions; orthogonal; preparation process; single factor

\section{Introduction}

Acid mine drainage (AMD) is a major pollution source in mining areas [1,2]. AMD has a $\mathrm{pH}<3$, and contains high concentrations of toxic elements, such as heavy metal ions, which cannot be reused [3,4]. If AMD is discharged into the environment without treatment, it can directly harm humans, animals, and plants [5,6], especially when it contains heavy metals like $\mathrm{Pb}(\mathrm{II}), \mathrm{Cd}(\mathrm{II})$, and $\mathrm{Cr}(\mathrm{III})[7,8]$. Highly efficient synergistic treatment methods and novel and cheap protective materials against AMD for the mining environment are a topic of cutting-edge research in academia and practice $[9,10]$. 
Current techniques for treating AMD containing heavy metals include the neutralization precipitation [11], electrochemical [12], membrane separation [13-15], microbial [16,17], constructed wetland [18], and adsorption [19,20] methods. Neutralization precipitation and adsorption are widely used [21,22]. However, neutralization precipitation requires a large amount of chemical agents, such as neutralizer and flocculent $[23,24]$, which leads to difficulties in solid-liquid separation and high processing costs $[25,26]$. Besides various adsorbent materials, activated carbon is frequently used for adsorption, but has a low adsorption capacity for heavy metal ions, has high costs, and cannot neutralize acid [27-29]. At present, most treatments use a single method, and the treatment effect is poor. If two methods are connected in series, the process flow is long, and the processing cost is high [30].

Bentonite is a good substitute for activated carbon. It is a clay with montmorillonite as its primary component [31,32]. Montmorillonite is a type of 2:1 layered silicate composed of a layer of alumino-oxygen octahedra sandwiched between two layers of silica-oxygen tetrahedra. Because of lattice displacement, electronegativity, and ion exchange in montmorillonite, as well as its large surface area, bentonite has a strong ability to adsorb metal cations [33]. Moreover, bentonite is an inexpensive and excellent mineral with abundant reserves in China and can be used to remove metal cations in AMD. However, it cannot neutralize acid. Steel slag is a type of metallurgical by-product, whose main phase is calcium glass. As a solid waste, steel slag recycling and utilization contributes to environmental pollution. Due to mineral compositions such as calcium glass, steel slag can release alkalinity in aqueous solution [34-36], which can be used to neutralize AMD acidity.

In this study, bentonite-steel slag composite particles (BSC) were developed as an adsorbent. These particles exploit the excellent adsorption of bentonite to heavy metal cations and the ability of steel slag to release alkalinity, neutralize acid, and precipitate heavy metal ions. The composite particles not only release alkalinity and neutralize acid, but also induce a synergistic adsorption-coagulation effect to remove heavy metal ions. These particles utilize solid waste, greatly reduce the processing cost, allow solids and liquids to be easily separated, and have the effects of neutralization, adsorption, coagulation, and filtration. Single-factor and orthogonal experiments were performed to determine the optimum preparation of the composite particles. The isothermal adsorption data of the optimum BSC were analyzed using the Langmuir, Freundlich, Dubinin-Radushkevich (D-R), and Brunauer-Emmett-Teller (BET) models. The Langmuir and BET models led to the best isotherms. A synergistic adsorption-coagulation effect occurred, leading to the appearance of multiple layers locally on the surface of BSC, which satisfied the BET model. To gain an insight into the preparation mechanism of BSC, the morphology, surface analysis, crystal and chemical structure of bentonite, steel slag, uncalcined BSC, and optimum BSC are studied using scanning electron microscopy (SEM), BET, X-ray powder diffraction (XRD), and Fourier-transform infrared spectroscopy (FTIR), respectively. In this study, a theoretical foundation is established for the mass production of BSC; this is achieved by determining various factors: the optimum preparation conditions, corresponding isothermal adsorption models, and the optimum preparation mechanism. BSC are a new type of multifunctional protective material for mining environments that can realize highly efficient and synergistic treatment of heavy metal ions in AMD.

\section{Materials and Methods}

\subsection{Materials and Chemicals}

The Na-bentonite was obtained from Jin Shi bentonite mining co., Ltd. in Fuxin City, Liaoning Province. The Na-bentonite was crushed and passed through a sieve with a 200-mesh size $(<74 \mu \mathrm{m})$. Steel slag was obtained from Zhong Tian Steel Plant in Fuxin City, Liaoning Province. The slag was crushed and passed through a 200-mesh sieve $(<74 \mu \mathrm{m})$. Table 1 presents the chemical composition of the bentonite and steel slag. The concentration of the heavy metals ( $\mathrm{Pb}(\mathrm{II}), \mathrm{Cd}(\mathrm{II})$, and $\mathrm{Cr}(\mathrm{III}))$ in the experimental water samples was adjusted to $50 \mathrm{mg} / \mathrm{L}$. The $\mathrm{pH}$ value was from 3.0 to 3.5 . The following 
analytically pure chemicals were also used: methyl orange reagent, phenolphthalein reagent, $\mathrm{Na}_{2} \mathrm{CO}_{3}$, $\mathrm{HCl}, \mathrm{NaOH}, \mathrm{HNO}_{3}, \mathrm{~Pb}\left(\mathrm{NO}_{3}\right)_{2}, \mathrm{Cd}\left(\mathrm{NO}_{3}\right)_{2} \cdot 4 \mathrm{H}_{2} \mathrm{O}$, and $\mathrm{Cr}\left(\mathrm{NO}_{3}\right)_{3} \cdot 9 \mathrm{H}_{2} \mathrm{O}$.

Table 1. Chemical composition of the bentonite sample and steel slag.

\begin{tabular}{ccc}
\hline \multirow{2}{*}{ Constituent } & \multicolumn{2}{c}{ Mass Percentage (\%) } \\
\cline { 2 - 3 } & Bentonite & Steel Slag \\
\hline $\mathrm{SiO}_{2}$ & 71.39 & 12.33 \\
$\mathrm{Al}_{2} \mathrm{O}_{3}$ & 14.4 & 0.18 \\
$\mathrm{Na}_{2} \mathrm{O}$ & 1.98 & 0 \\
$\mathrm{Fe}_{2} \mathrm{O}_{3}$ & 1.71 & 38.83 \\
$\mathrm{MgO}$ & 1.52 & 10 \\
$\mathrm{CaO}$ & 1.20 & 32.73 \\
$\mathrm{~K}_{2} \mathrm{O}$ & 0.44 & 0 \\
$\mathrm{TiO}_{2}$ & $<0.1$ & 0 \\
$\mathrm{MnO}$ & 0 & 3.29 \\
$\mathrm{P}_{2} \mathrm{O}_{5}$ & 0 & 1.12 \\
\hline
\end{tabular}

\subsection{Calculation}

The quantity of heavy metal ions adsorbed by the BSC was calculated as follows:

$$
q_{t}=\frac{\left(C_{0}-C_{t}\right) V}{m}
$$

where $q_{t}$ is the amount of solute adsorbed per unit adsorbent at any time $(\mathrm{mg} / \mathrm{g}) ; C_{0}$ and $C_{t}$ are the initial concentration and concentration at any time, respectively, of the solute in the solution $(\mathrm{mg} / \mathrm{L}) ; V$ is the volume of the water sample (L); and $m$ is the mass of the BSC (g).

The alkalinity (measured in $\mathrm{CaCO}_{3}$ ) in this experiment was determined through acid-base titration (SL 83-1994) and was calculated as follows:

$$
\text { Total alkalinity }(\mathrm{mg} / \mathrm{L})=\frac{C \times(P+M) \times 50.05}{V} \times 1000
$$

where $C$ is the concentration of the $\mathrm{HCl}$ standard solution (mol/L); $P$ is the $\mathrm{HCl}$ consumption after the addition of the phenolphthalein reagent $(\mathrm{mL}) ; \mathrm{M}$ is the $\mathrm{HCl}$ consumption after the addition of the methyl orange reagent $(\mathrm{mL}) ; V$ is the volume of the water sample $(\mathrm{mL})$, and 50.05 is the molar mass of calcium carbonate $\left(1 / 2 \mathrm{CaCO}_{3}\right)(\mathrm{g} / \mathrm{mol})$.

The loss rate of the composite particles was calculated as follows:

$$
\eta=\frac{m_{1}-m_{2}}{m_{1}} \times 100 \%
$$

where $\eta$ is the loss rate of composite particles (\%), $m_{1}$ is the initial mass of composite particles (g), and $m_{2}$ is the mass of the composite particles after drying $(\mathrm{g})$.

\subsection{Preparation of the $B S C$}

Bentonite and steel slag powder were mixed at a given proportion, to which a given mass of $\mathrm{Na}_{2} \mathrm{CO}_{3}$ was added. Herein, bentonite functioned as the adsorbent, steel slag imparted alkalinity, and $\mathrm{Na}_{2} \mathrm{CO}_{3}$ was employed as the pore-opening agent and decomposed into $\mathrm{CO}_{2}$ upon heating. After the mixture was evenly mixed, an appropriate amount of deionized water was added and stirred, and composite particles with the same particle size (calcination particle size) were made with an extrusion granulator. Granular adsorbents are known to facilitate solid-liquid separation for industrial applications. The particles were aged for a given period of time (aging time); this was to achieve a complete permeation of the raw material particles by water. A deeper permeation resulted in the pores 
being generated by the evaporation of water being significantly smaller during calcination; this was conducive to increasing the specific surface area of the particles. They were then heated in a crucible in a muffle furnace from the preheated temperature of $250{ }^{\circ} \mathrm{C}$ to a given temperature (calcination temperature) for a given time (calcination time). Calcination could not only increase the strength of the particles but also led to the production of a large amount of water vapor and $\mathrm{CO}_{2}$; this resulted in an increase in the production of pores by the particles and enhanced the specific surface area, which in turn improved the adsorption performance. The particles were then cooled naturally after calcination to produce the adsorbent.

\subsection{Single-Factor Experiment}

Different bentonite and steel slag composite particles were prepared for different proportions of the bentonite and steel slag, contents of $\mathrm{Na}_{2} \mathrm{CO}_{3}$, aging times, calcination particle sizes, calcination temperatures, and calcination times. A batch test was performed to study the adsorption performances of the composite particles prepared under different conditions. The dosage was fixed at $10 \mathrm{~g} / \mathrm{L}$, and the initial concentration of the water sample containing heavy metal ions was $50 \mathrm{mg} / \mathrm{L}$. A conical flask was placed in a thermostatic oscillator; the reaction temperature was $25^{\circ} \mathrm{C}$, and the rotating speed was $100 \mathrm{rpm}$. Water samples were then removed and filtered within the prescribed times of $20 \mathrm{~min}, 40 \mathrm{~min}, 60 \mathrm{~min}, 90 \mathrm{~min}$, and $120 \mathrm{~min}$. The concentration of residual ions in the filtrate was determined with a flame atomic absorption spectrophotometer (AAS) (Hitachi Z-2000, Tokyo, Japan), and the adsorption quantity was calculated according to Equation (1). An acid-base titration method (SL 83-1994) was performed, and the alkalinity was calculated according to Equation (2). The same amounts of composite particles and deionized water as in the adsorption experiment were added to the conical flask and reacted at a temperature of $25^{\circ} \mathrm{C}$ and rotation speed of $100 \mathrm{rpm}$ for $120 \mathrm{~min}$. Particles were then dried in an oven at $105^{\circ} \mathrm{C}$ until they reached a constant weight. The particle loss rate was calculated according to Equation (3). In order to ensure the reliability of the test results, the batch tests were conducted in parallel in two groups to obtain the mean values, and blank sample tests were conducted to test the initial concentration of the heavy metal ions.

\subsection{Orthogonal Experiment}

Based on the results of the single-factor experiment, the bentonite-steel slag proportion, $\mathrm{Na}_{2} \mathrm{CO}_{3}$ content, calcination temperature, and calcination time were selected as the main influencing factors for an L9 $\left(4^{3}\right)$ orthogonal experiment $[37,38]$. Table 2 presents the design of the orthogonal experiment. The adsorption amount, alkalinity release amount, and loss rate at $120 \mathrm{~min}$ in the orthogonal experiment were measured and calculated in the same manner as that in the single-factor experiment.

Table 2. Table of factors and levels.

\begin{tabular}{ccccc}
\hline & \multicolumn{4}{c}{ Factors } \\
\cline { 2 - 5 } Levels & $\begin{array}{c}\text { Ratio } \\
\text { (Bentonite: Steel Slag) }\end{array}$ & $\begin{array}{c}\mathbf{N a}_{2} \mathbf{C O}_{3} \text { Content } \\
\mathbf{( \% )}\end{array}$ & $\begin{array}{c}\text { Calcination } \\
\text { Temperature }\left({ }^{\circ} \mathbf{C}\right)\end{array}$ & $\begin{array}{c}\text { Calcination Time } \\
\text { (min) }\end{array}$ \\
\hline 1 & $7: 3$ & 3 & 450 & 40 \\
2 & $6: 4$ & 5 & 500 & 60 \\
3 & $5: 5$ & 8 & 550 & 90 \\
\hline
\end{tabular}

\subsection{Adsorption Isotherms}

Batch tests were conducted to study $\mathrm{Pb}(\mathrm{II}), \mathrm{Cd}(\mathrm{II})$, and $\mathrm{Cr}$ (III) adsorption at different solution concentrations. The BSC dosage was fixed at $10 \mathrm{~g} / \mathrm{L}$ with initial solute concentrations of $100 \mathrm{mg} / \mathrm{L}$, $200 \mathrm{mg} / \mathrm{L}, 400 \mathrm{mg} / \mathrm{L}, 500 \mathrm{mg} / \mathrm{L}$, and $600 \mathrm{mg} / \mathrm{L}$. All samples were equilibrated for $24 \mathrm{~h}$ in a thermostatic shaker $\left(25^{\circ} \mathrm{C}, 100 \mathrm{rpm}\right)$; then, the equilibrium $\mathrm{Pb}$ (II), $\mathrm{Cd}$ (II), and $\mathrm{Cr}$ (III) concentrations were measured using the AAS to calculate the amount of $\mathrm{Pb}(\mathrm{II}), \mathrm{Cd}(\mathrm{II})$, and $\mathrm{Cr}(\mathrm{III})$ adsorbed on the sorbent. 


\subsection{Microstructure Characterization}

To investigate the modification mechanism of BSC, the raw materials and optimum BSC were characterized. The morphology and microstructure of the raw materials and optimum BSC were observed using an FEI Quanta 200 SEM. The specific surface area, average pore size, and total pore volume of the optimum BSC were estimated from Brunauer-Emmett-Teller (BET) nitrogen adsorption-desorption isotherms at 77.3 K using a Nova 2200e instrument (Quantachrome, Boynton Beach, FL, USA). X-ray diffraction (XRD) patterns were recorded in an XRD6100 (Shimadzu, Kyoto, Japan) diffractometer using monochromatic $\mathrm{Cu} \mathrm{K} \alpha$ radiation $(\lambda=0.154 \mathrm{~nm})$, operating at $40 \mathrm{kV}$ and $30 \mathrm{~mA}$ over a $2 \theta$ range from $5^{\circ}$ to $80^{\circ}$ at a scanning rate of $6^{\circ} / \mathrm{min}$. Fourier-transform infrared spectroscopy (FTIR) studies were carried out on a Nicolet IS10 (Thermo Fisher, Waltham, MA, USA) FTIR spectrometer (KBr pellet, Houston, TX, USA) in the range of $4000-400 \mathrm{~cm}^{-1}$.

\section{Results and Discussion}

\subsection{Single-Factor Experiment}

\subsubsection{Determination of the Bentonite-Steel Slag Proportion}

To optimize the bentonite-steel slag proportion, the $\mathrm{Na}_{2} \mathrm{CO}_{3}$ content was set to $5 \%$ of the total mass of the composite material, the aging time was set to $24 \mathrm{~h}$, the calcination particle size was set to $1-2 \mathrm{~mm}$, the calcination temperature was set to $500^{\circ} \mathrm{C}$, and the calcination time was set to $60 \mathrm{~min}$. Different composite particles were produced with bentonite-steel slag proportions of 9:1, 8:2, 7:3, 6:4, and 5:5. Figure 1 shows the results for the adsorption amount, alkalinity release amount, and loss rate. Increasing the proportion of steel slag increased the adsorption quantity of heavy metal ions and alkalinity release quantity and decreased the loss rate. Composite particles with a proportion of 5:5 had the best removal of heavy metal ions. The adsorption quantities of $\mathrm{Pb}, \mathrm{Cd}$, and $\mathrm{Cr}$ were $4.98 \mathrm{mg} / \mathrm{g}$, $4.95 \mathrm{mg} / \mathrm{g}$, and $4.82 \mathrm{mg} / \mathrm{g}$, respectively, at $120 \mathrm{~min}$. The composite particle loss rate was lowest at $0.98 \%$, and the alkalinity release quantity was highest at $12.26 \mathrm{mg} / \mathrm{g}$. The adsorption quantities $\mathrm{of} \mathrm{Pb}, \mathrm{Cd}$, and $\mathrm{Cr}$ by composite particles with the proportion of $6: 4$ were $4.83 \mathrm{mg} / \mathrm{g}, 4.79 \mathrm{mg} / \mathrm{g}$, and $4.53 \mathrm{mg} / \mathrm{g}$, respectively; the loss rate was $1.27 \%$, and the alkalinity release quantity was $11.04 \mathrm{mg} / \mathrm{g}$. The adsorption quantities of $\mathrm{Pb}$ (II), $\mathrm{Cd}(\mathrm{II})$, and $\mathrm{Cr}(\mathrm{III})$ of composite particles with the proportion of $7: 3$ were $4.71 \mathrm{mg} / \mathrm{g}$, $4.64 \mathrm{mg} / \mathrm{g}$, and $4.32 \mathrm{mg} / \mathrm{g}$, respectively. The loss rate was $2.77 \%$, and the alkalinity release quantity was $10.06 \mathrm{mg} / \mathrm{g}$. The composite particles with proportions of 8:2 and 9:1 had lower adsorption quantity and alkalinity, and the loss rate was above $3.4 \%$. The experimental results showed that steel slag plays an active role in the removal of heavy metal ions by releasing alkalinity, increasing ion removal, and reducing the loss rate. However, if the composite material had more steel slag than bentonite it could not be made into particles, and the particles were easily pulverized before being calcined. 


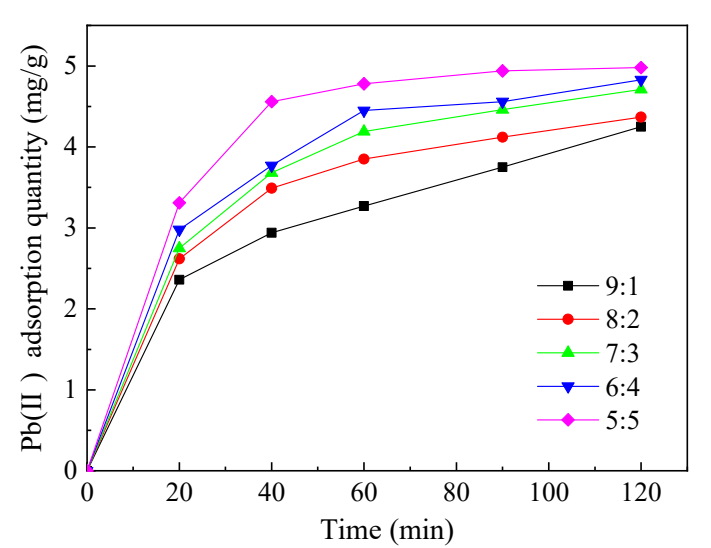

(a)

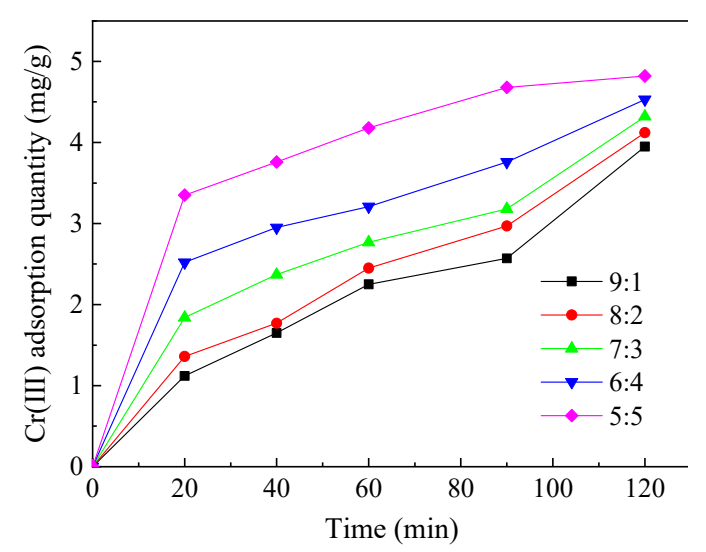

(c)

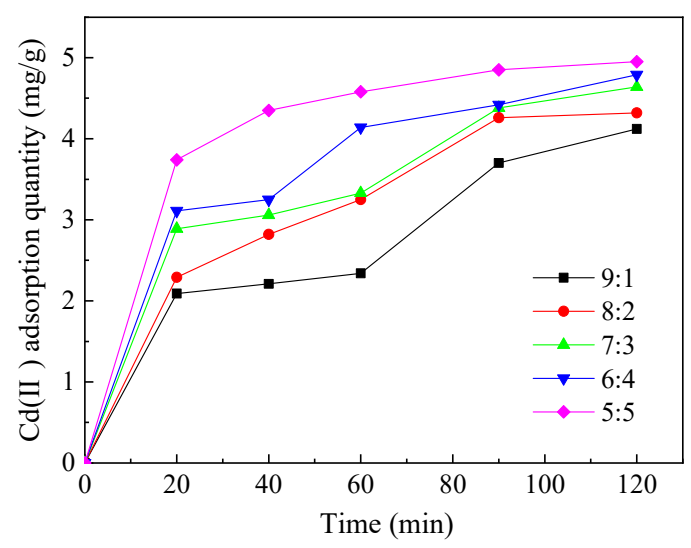

(b)

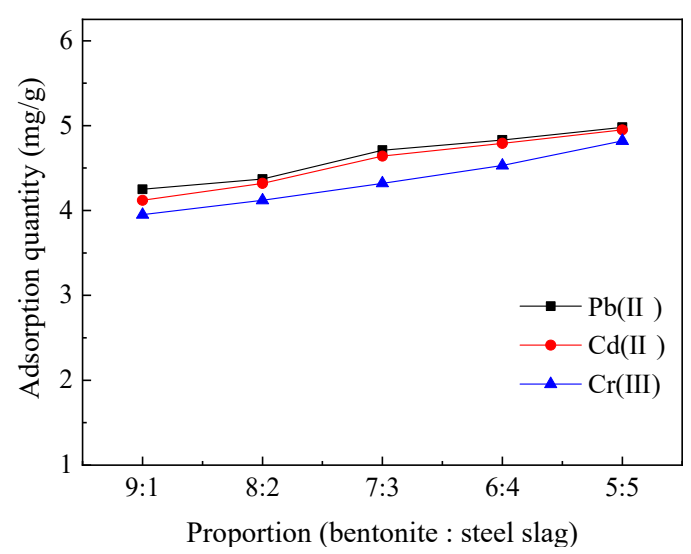

(d)

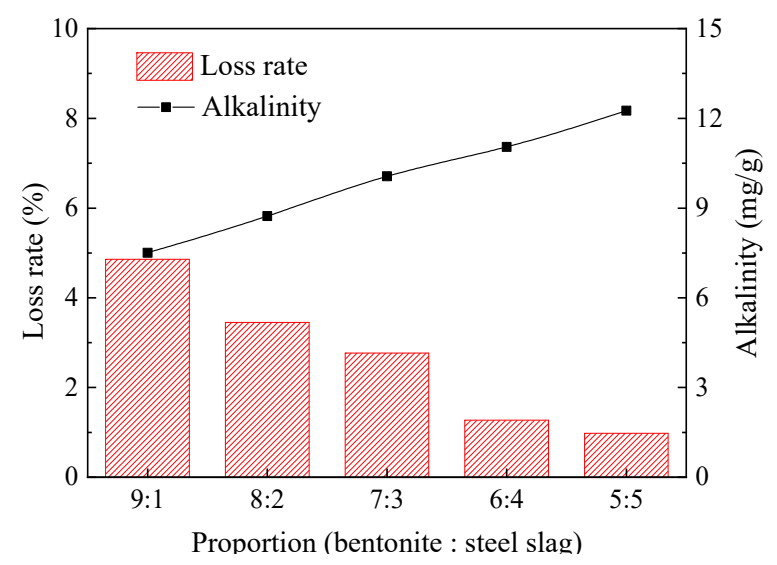

(e)

Figure 1. Adsorption effect of heavy metal ions, loss rate, and alkalinity release amount by composite particles with different proportions. (a) represents the change of $\mathrm{Pb}$ (II) adsorption quantity with time. (b) represents the change of $\mathrm{Cd}$ (II) adsorption quantity with time. (c) represents the change of $\mathrm{Cr}$ (III) adsorption quantity with time. (d) represents the adsorption quantity by composite particles with different proportions at $120 \mathrm{~min}$. (e) represents the alkalinity release amount and loss rate by composite particles with different proportions at $120 \mathrm{~min}$.

The hydrolysis reaction of steel slag made the solution alkaline, and the heavy metal ions reacted to form metal hydroxides. As the proportion of steel slag increased, more alkalinity was released, more hydroxides were generated, and the removal efficiency of heavy metal ions improved. Meanwhile, the metal hydroxides adsorbed on the particle surfaces as a carrier to adsorb heavy metal ions; this 
resulted in a synergistic adsorption-coagulation effect. Because of the high mechanical strength of the steel slag, increasing its proportion reduced the particle loss rate [39,40]. In conclusion, the optimum proportion of bentonite and steel slag was 5:5.

The main hydrolysis reactions [41] of steel slag in the solution were as follows:

$$
\begin{aligned}
2 \mathrm{Na}_{4} \mathrm{SiO}_{4}+4 \mathrm{H}_{2} \mathrm{O} & \rightarrow \mathrm{Na}_{6} \mathrm{Si}_{2} \mathrm{O}_{7} \cdot 3 \mathrm{H}_{2} \mathrm{O}+2 \mathrm{NaOH} \\
2 \mathrm{Ca}_{2} \mathrm{SiO}_{4}+4 \mathrm{H}_{2} \mathrm{O} & \rightarrow \mathrm{Ca}_{3} \mathrm{Si}_{2} \mathrm{O}_{7} \cdot 3 \mathrm{H}_{2} \mathrm{O}+\mathrm{Ca}(\mathrm{OH})_{2} \\
2 \mathrm{Ca}_{3} \mathrm{SiO}_{5}+6 \mathrm{H}_{2} \mathrm{O} & \rightarrow \mathrm{Ca}_{3} \mathrm{Si}_{2} \mathrm{O}_{7} \cdot 3 \mathrm{H}_{2} \mathrm{O}+3 \mathrm{Ca}(\mathrm{OH})_{2}
\end{aligned}
$$

Then,

$$
\mathrm{Ca}(\mathrm{OH})_{2} \rightarrow \mathrm{Ca}^{2+}+2 \mathrm{OH}^{-}
$$

\subsubsection{Determination of the $\mathrm{Na}_{2} \mathrm{CO}_{3}$ Content}

To optimize the $\mathrm{Na}_{2} \mathrm{CO}_{3}$ content, the bentonite-steel slag proportion was set to 5:5, the aging time was set to $24 \mathrm{~h}$, the calcination particle size was set to $1-2 \mathrm{~mm}$, the calcination temperature was set to $500{ }^{\circ} \mathrm{C}$, and the calcination time was set to $60 \mathrm{~min}$. Different composite particles were produced with $\mathrm{Na}_{2} \mathrm{CO}_{3}$ contents of $0 \%, 3 \%, 5 \%, 8 \%$, and $10 \%$. Figure 2 shows the results for the adsorption amount, alkalinity release amount, and loss rate. When the $\mathrm{Na}_{2} \mathrm{CO}_{3}$ content was increased from $3 \%$ to $10 \%$, the adsorption rate of the composite particles to ions increased significantly, the loss rate decreased, and the alkalinity release quantity increased. The composite particles with a $\mathrm{Na}_{2} \mathrm{CO}_{3}$ content of $0 \%$ had the best adsorption effect on heavy metal ions, with the highest alkalinity release, but the loss rate was as high as $100 \%$, so the required strength could not be achieved. Composite particles with $3 \% \mathrm{Na}_{2} \mathrm{CO}_{3}$ content had adsorption quantities of $\mathrm{Pb}(\mathrm{II}), \mathrm{Cd}(\mathrm{II})$, and $\mathrm{Cr}$ (III) of $4.65 \mathrm{mg} / \mathrm{g}, 3.72 \mathrm{mg} / \mathrm{g}$, and $3.15 \mathrm{mg} / \mathrm{g}$, respectively. The loss rate was $5.21 \%$, and the alkalinity was $10.26 \mathrm{mg} / \mathrm{g}$. Composite particles with $\mathrm{Na}_{2} \mathrm{CO}_{3}$ contents of $5 \%, 8 \%$, and $10 \%$ showed little difference in the adsorption amount, loss rate, and alkalinity release amount and could reach a high standard. Waste occurred when the $\mathrm{Na}_{2} \mathrm{CO}_{3}$ content was $10 \%$.

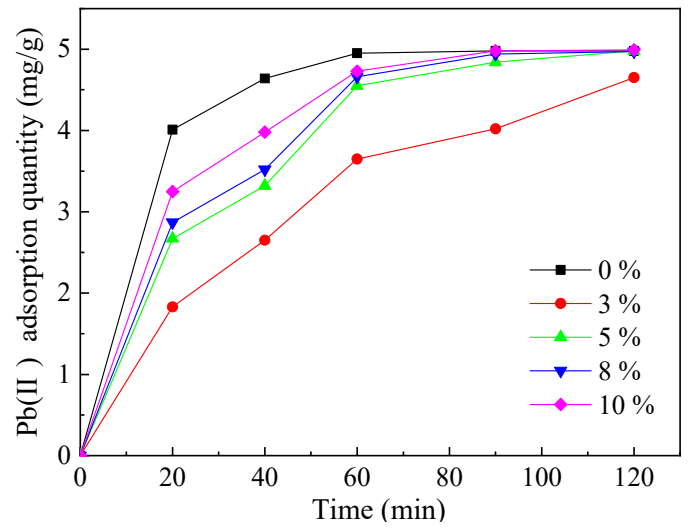

(a)

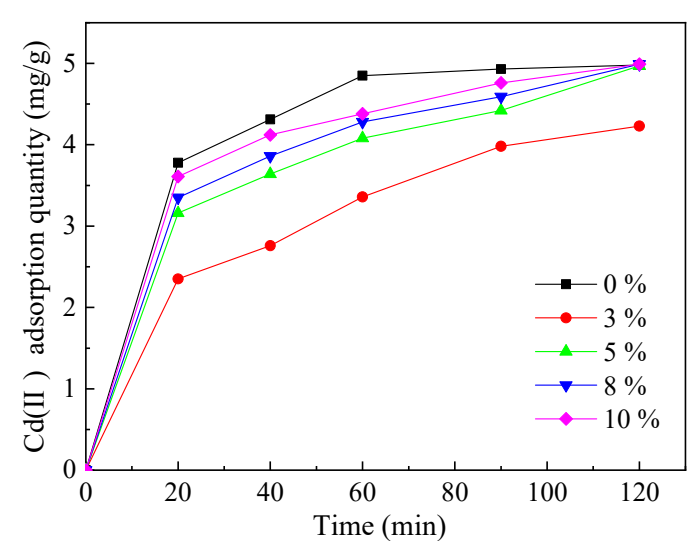

(b)

Figure 2. Cont. 


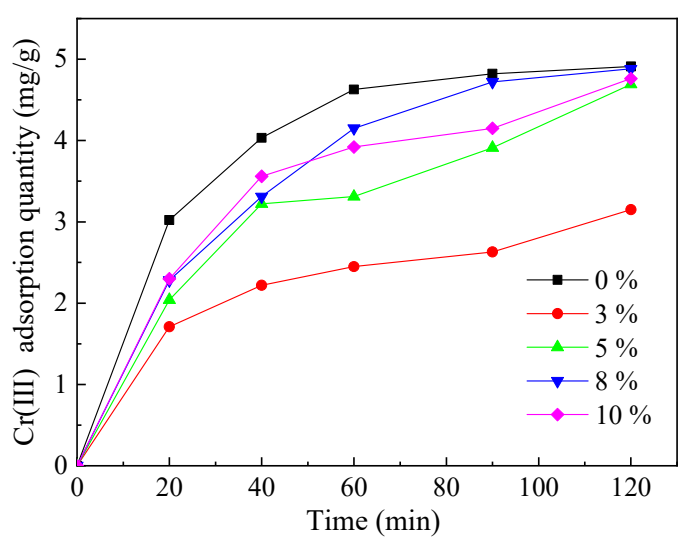

(c)

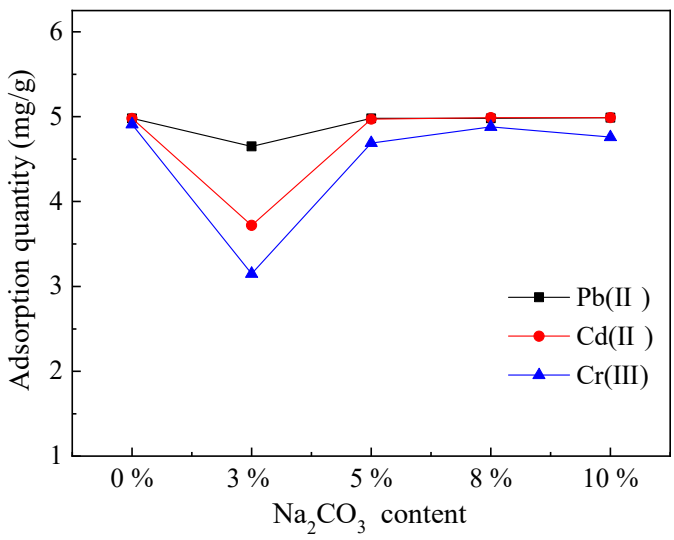

(d)

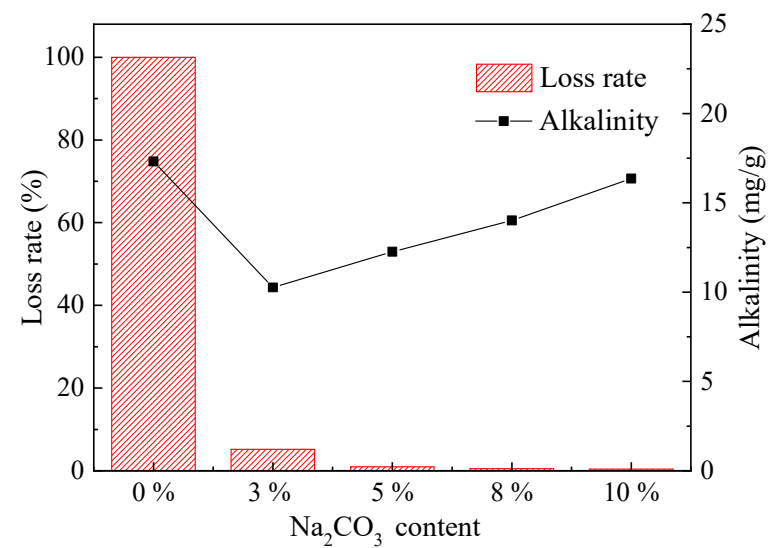

(e)

Figure 2. Adsorption effect of heavy metal ions, loss rate, and alkalinity release amount by composite particles with different contents of $\mathrm{Na}_{2} \mathrm{CO}_{3}$. (a) represents the change of $\mathrm{Pb}$ (II) adsorption quantity with time. (b) represents the change of $\mathrm{Cd}$ (II) adsorption quantity with time. (c) represents the change of $\mathrm{Cr}(\mathrm{III})$ adsorption quantity with time. (d) represents the adsorption quantity by composite particles with different contents of $\mathrm{Na}_{2} \mathrm{CO}_{3}$ at $120 \mathrm{~min}$. (e) represents the alkalinity release amount and loss rate by composite particles with different contents of $\mathrm{Na}_{2} \mathrm{CO}_{3}$ at $120 \mathrm{~min}$.

Because it is a pore-opening agent, increasing the $\mathrm{Na}_{2} \mathrm{CO}_{3}$ content increased the $\mathrm{CO}_{2}$ during calcine. Increasing the gas channels and pores inside the particles increased the active centers that could be provided for adsorption. A large number of channels and pores also facilitated the release of alkalinity of the particles. However, the $\mathrm{Na}_{2} \mathrm{CO}_{3}$ content needed to be controlled within a suitable range, otherwise a large amount of $\mathrm{CO}_{2}$ gas would collapse the internal structure of the particles. $\mathrm{Na}_{2} \mathrm{CO}_{3}$ also acted as a binder and could react with the mineral components of $\mathrm{SiO}_{2}$ and $\mathrm{Al}_{2} \mathrm{O}_{3}$ in the composite particles to form silicate compounds. Increasing the $\mathrm{Na}_{2} \mathrm{CO}_{3}$ content formed more silicate compounds. The cohesiveness of the composite particles increased, and the loss rate decreased [42,43]. Although $\mathrm{Na}_{2} \mathrm{CO}_{3}$ can improve the adsorption performance of composite particles and reduce the loss rate, industrial $\mathrm{Na}_{2} \mathrm{CO}_{3}$ costs $\$ 185 / t$, which is relatively expensive. In conclusion, the optimum $\mathrm{Na}_{2} \mathrm{CO}_{3}$ content was determined to be $5 \%$.

\subsubsection{Determination of the Aging Time}

To determine the aging time, the bentonite-steel slag proportion was set to 5:5, the $\mathrm{Na}_{2} \mathrm{CO}_{3}$ content was set to $5 \%$, the calcination particle size was set to $1-2 \mathrm{~mm}$, the calcination temperature was set to $500{ }^{\circ} \mathrm{C}$, and the calcination time was set to $60 \mathrm{~min}$. Different composite particles were produced at aging times of $0 \mathrm{~h}, 6 \mathrm{~h}, 12 \mathrm{~h}, 18 \mathrm{~h}, 24 \mathrm{~h}$, and $30 \mathrm{~h}$. Figure 3 shows the results for the adsorption 
amount, alkalinity release amount, and loss rate. As the aging time increased, the adsorption amount of heavy metal ions first increased and then decreased. The adsorption amount was highest at an aging time of $12 \mathrm{~h}$. The alkalinity release amount first increased and then decreased with aging time. The range of variation was stable between 10.13 and $13.04 \mathrm{mg} / \mathrm{g}$, and the alkalinity release amount was highest at $13.04 \mathrm{mg} / \mathrm{g}$, with an aging time of $12 \mathrm{~h}$. The loss rate first decreased and then increased with aging time and ranged from $1.62 \%$ to $1.07 \%$. The composite particle loss rate was $1.19 \%$ when the aging time was $12 \mathrm{~h}$, and the loss rate was lowest at $1.07 \%$ with an aging time of $18 \mathrm{~h}$.

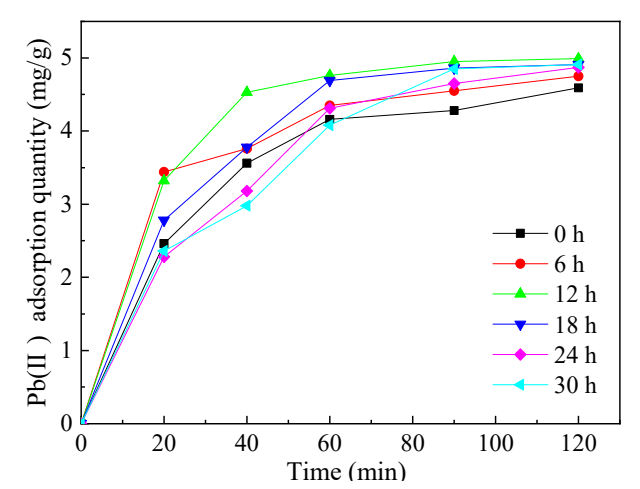

(a)

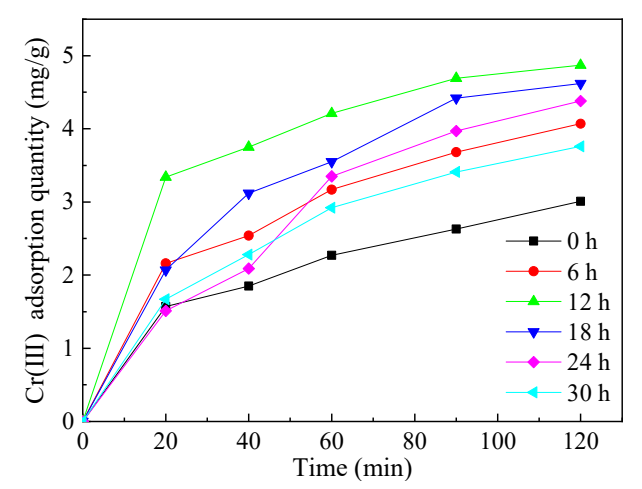

(c)

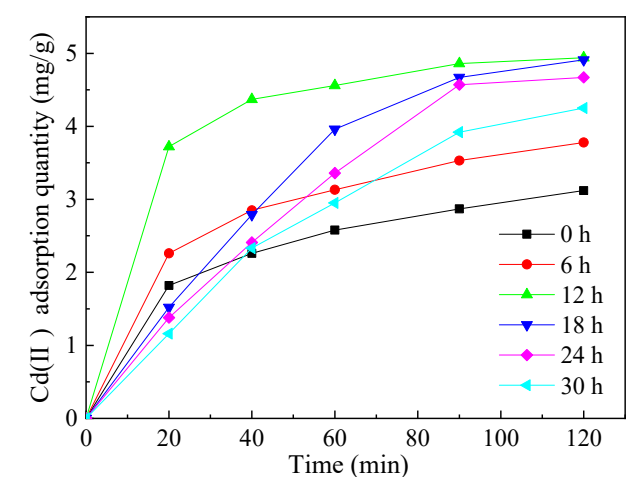

(b)

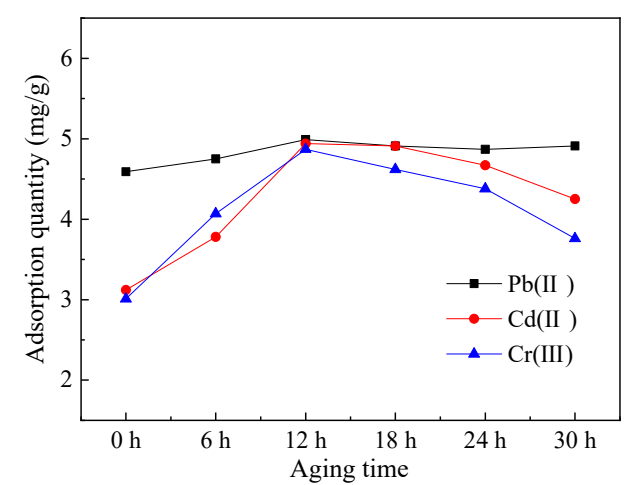

(d)

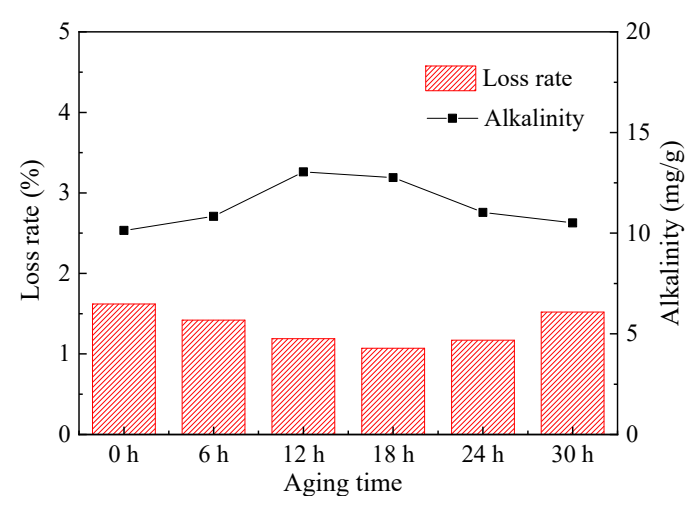

(e)

Figure 3. Adsorption effect of heavy metal ions, loss rate, and alkalinity release amount by composite particles with different aging times. (a) represents the change of $\mathrm{Pb}$ (II) adsorption quantity with time. (b) represents the change of $\mathrm{Cd}(\mathrm{II})$ adsorption quantity with time. (c) represents the change of $\mathrm{Cr}$ (III) adsorption quantity with time. (d) represents the adsorption quantity by composite particles with different aging times at $120 \mathrm{~min}$. (e) represents the alkalinity release amount and loss rate by composite particles with different aging times at $120 \mathrm{~min}$. 
On the one hand, aging was performed to uniformly wet the composite particles with water so that they could expand. On the other hand, as the composite material was calcined, a large amount of internal moisture evaporated, which caused the particles to disintegrate. When the aging time was increased from $0 \mathrm{~h}$ to $12 \mathrm{~h}$, the adsorption amount increased continuously to the maximum. This indicates that the materials had been uniformly infiltrated by water at $12 \mathrm{~h}$, and the particle expansion reached its maximum. At this time, the particles had a large specific surface area after calcination, a high adsorption amount, a high alkalinity release amount, and a low loss rate. When the aging time was further increased, the amount of adsorption decreased, the amount of alkalinity decreased, and the loss rate increased. This indicates that an overly long aging time was detrimental to the adsorption of heavy metal ions by the composite particles [44-46]. It was concluded that the aging time may change the distribution and arrangement of the internal structure of the composite particles. Thus, the optimum aging time was determined to be $12 \mathrm{~h}$.

\subsubsection{Determination of the Calcination Particle Size}

To determine the calcination particle size, the bentonite-steel slag proportion was 5:5, the $\mathrm{Na}_{2} \mathrm{CO}_{3}$ content was $5 \%$, the aging time was $12 \mathrm{~h}$, the calcination temperature was $500{ }^{\circ} \mathrm{C}$, and the calcination time was $60 \mathrm{~min}$. Different composite particles were produced with calcination particle sizes of $1 \mathrm{~mm}$, $2 \mathrm{~mm}, 3 \mathrm{~mm}$, and $4 \mathrm{~mm}$. Figure 4 shows the results for the adsorption amount, alkalinity release amount, and loss rate. The adsorption effect increased with a smaller calcination particle size when the reaction time was kept the same. As the calcination particle size decreased, the adsorption rate and adsorption quantity increased. The composite particles with a calcination particle size of $1 \mathrm{~mm}$ adsorbed $5 \mathrm{mg} / \mathrm{g}, 5 \mathrm{mg} / \mathrm{g}$, and $4.95 \mathrm{mg} / \mathrm{g}$ of $\mathrm{Pb}(\mathrm{II}), \mathrm{Cd}(\mathrm{II})$, and $\mathrm{Cr}(\mathrm{III})$, respectively. The composite particles with a calcination particle size of $2 \mathrm{~mm}$ adsorbed $4.99 \mathrm{mg} / \mathrm{g}, 4.95 \mathrm{mg} / \mathrm{g}$, and $4.85 \mathrm{mg} / \mathrm{g}$ of $\mathrm{Pb}(\mathrm{II})$, $\mathrm{Cd}(\mathrm{II})$, and $\mathrm{Cr}(\mathrm{III})$, respectively. The composite particles with particle sizes of 1 and $2 \mathrm{~mm}$ showed excellent metal ion removal. A smaller calcination particle size increased the external specific surface area of the particles [47], so they could adsorb aggregated heavy metal ions and precipitates. When the calcination particle size was increased, the alkalinity release amount increased slightly, and the range of variation was small. The effect of the calcination particle size on the release of alkalinity could be neglected. Increasing the calcination particle size reduced the loss rate; the composite particles with calcination particle sizes of $1 \mathrm{~mm}, 2 \mathrm{~mm}, 3 \mathrm{~mm}$, and $4 \mathrm{~mm}$ had loss rates of $2.26 \%, 1.14 \%, 1.04 \%$, and $0.96 \%$, respectively. The composite particles with a particle size of $1 \mathrm{~mm}$ had a loss rate about twice that of the composite particles with a particle size of $2 \mathrm{~mm}$. In conclusion, the optimum calcination particle size was determined to be $2 \mathrm{~mm}$.

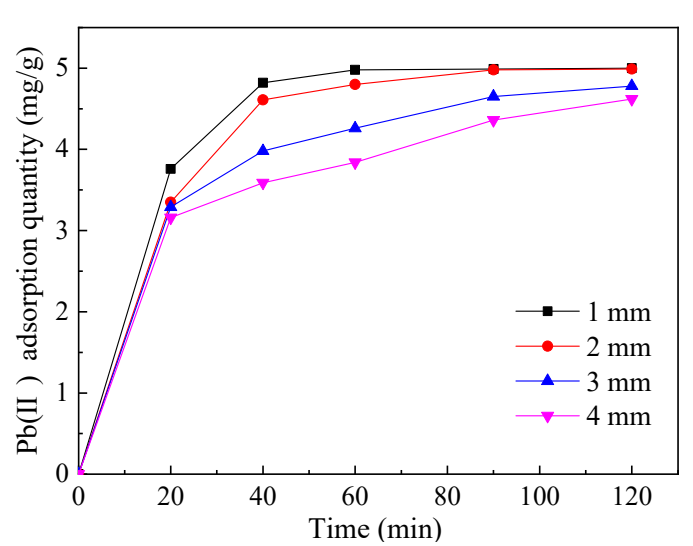

(a)

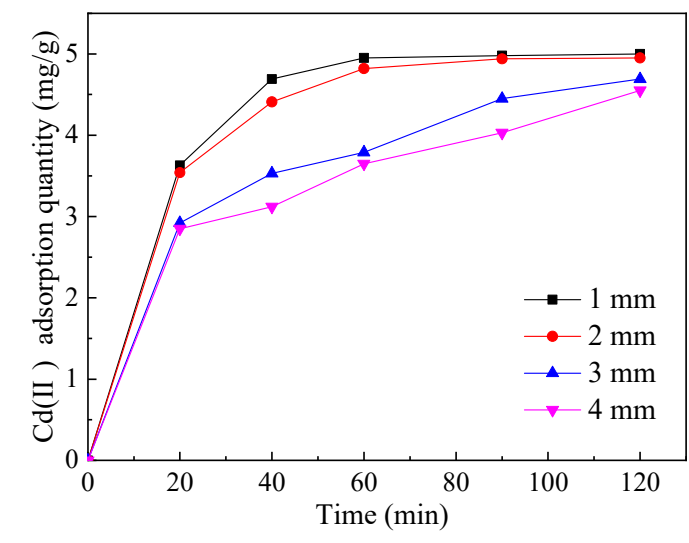

(b)

Figure 4. Cont. 


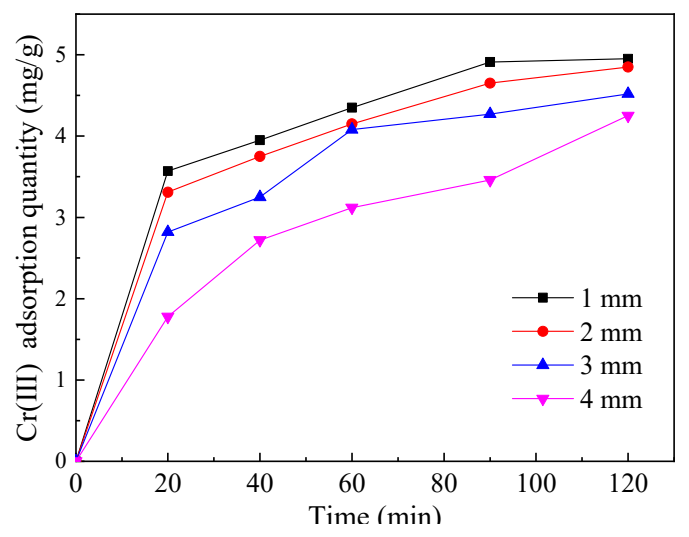

(c)

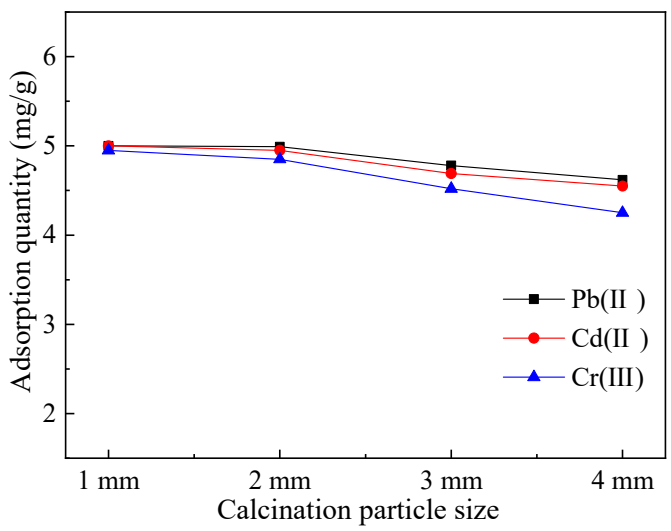

(d)

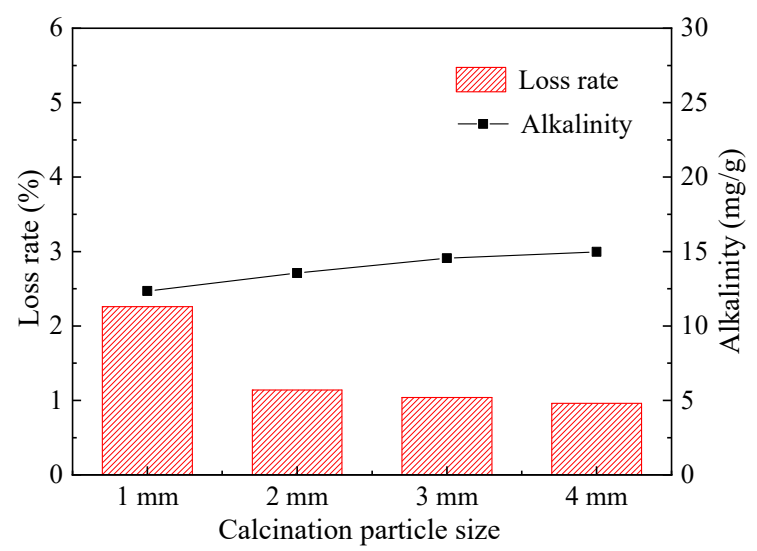

(e)

Figure 4. Adsorption effect of heavy metal ions, loss rate, and alkalinity release amount by composite particles with different calcination particle sizes. (a) represents the change of $\mathrm{Pb}$ (II) adsorption quantity with time. (b) represents the change of $\mathrm{Cd}(\mathrm{II})$ adsorption quantity with time. (c) represents the change of $\mathrm{Cr}(\mathrm{III})$ adsorption quantity with time. (d) represents the adsorption quantity by composite particles with different calcination particle sizes at $120 \mathrm{~min}$. (e) represents the alkalinity release amount and loss rate by composite particles with different calcination particle sizes at $120 \mathrm{~min}$.

\subsubsection{Determination of the Calcination Temperature}

To determine the calcination temperature, the bentonite-steel slag proportion was 5:5, the $\mathrm{Na}_{2} \mathrm{CO}_{3}$ content was $5 \%$, the aging time was $12 \mathrm{~h}$, the calcination particle size was $2 \mathrm{~mm}$, and the calcination time was $60 \mathrm{~min}$. Different composite particles were produced at calcination temperatures of $400{ }^{\circ} \mathrm{C}$, $450{ }^{\circ} \mathrm{C}, 500{ }^{\circ} \mathrm{C}$, and $550^{\circ} \mathrm{C}$. Figure 5 shows the results for the adsorption amount, alkalinity release amount, and loss rate. As the calcination temperature increased, the adsorption amount, alkalinity release amount, and loss rate decreased. The composite particles with a calcination temperature of $400{ }^{\circ} \mathrm{C}$ had the greatest adsorption and alkalinity release, but the loss rate was as high as $100 \%$, so the required strength of the particles could not be achieved. The adsorption quantity reached $4.85 \mathrm{mg} / \mathrm{g}$ at the calcination temperatures of $450{ }^{\circ} \mathrm{C}$ and $500{ }^{\circ} \mathrm{C}$, and the alkalinity release amounts were $16.52 \mathrm{mg} / \mathrm{g}$ and $14.26 \mathrm{mg} / \mathrm{g}$, respectively. The composite particles calcined at $550^{\circ} \mathrm{C}$ had a poor ion removal effect and the lowest alkalinity release amount at $6.25 \mathrm{mg} / \mathrm{g}$. The loss rate was higher at $450{ }^{\circ} \mathrm{C}$ at $10.21 \%$. The loss rates at $500{ }^{\circ} \mathrm{C}$ and $550{ }^{\circ} \mathrm{C}$ were $1.18 \%$ and $0.56 \%$, respectively. 


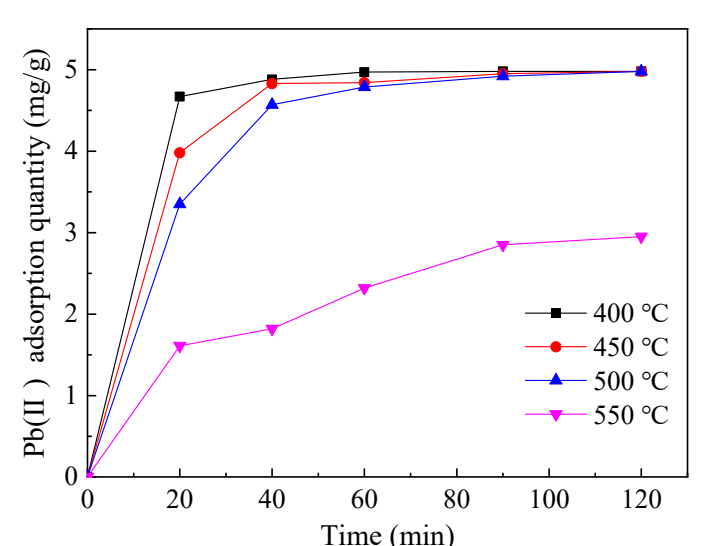

(a)

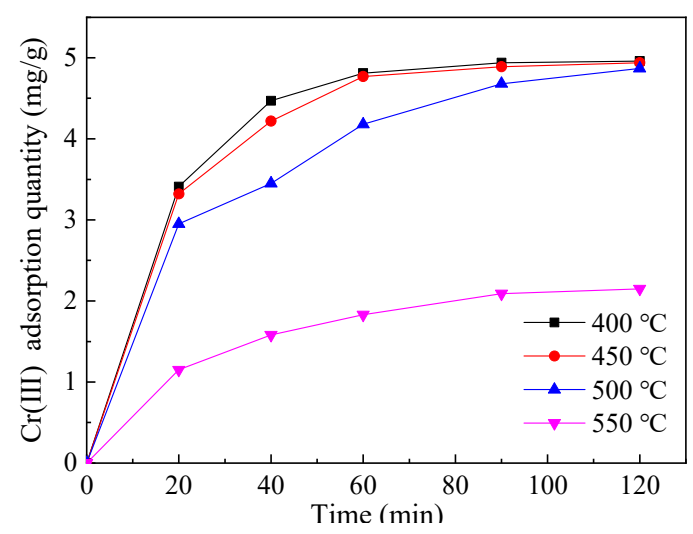

(c)

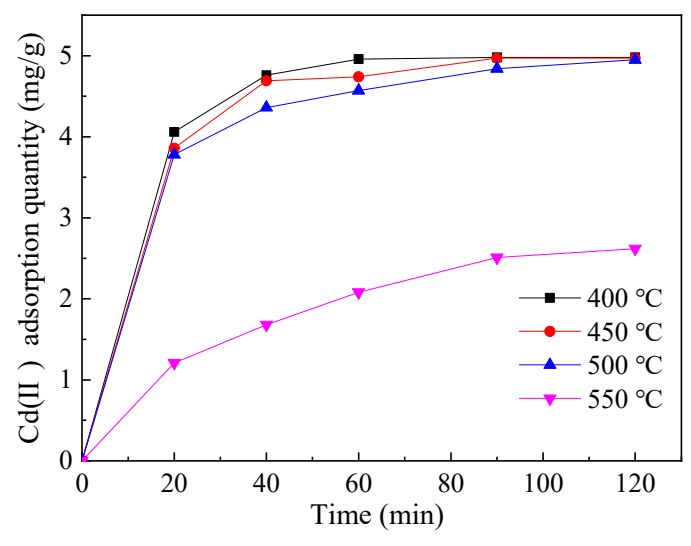

(b)

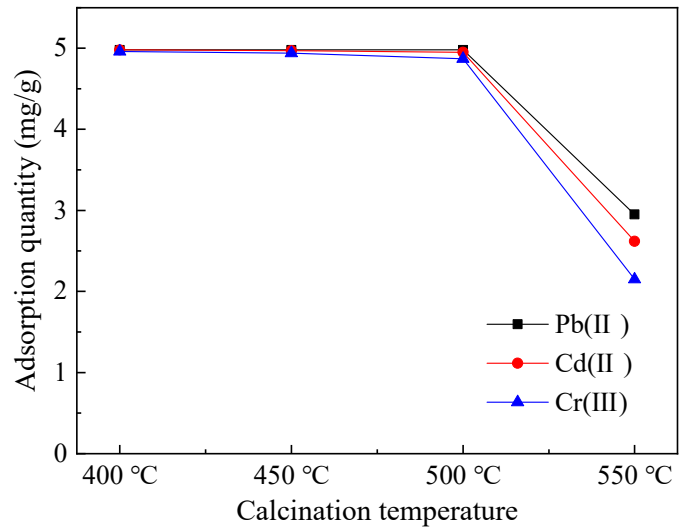

(d)

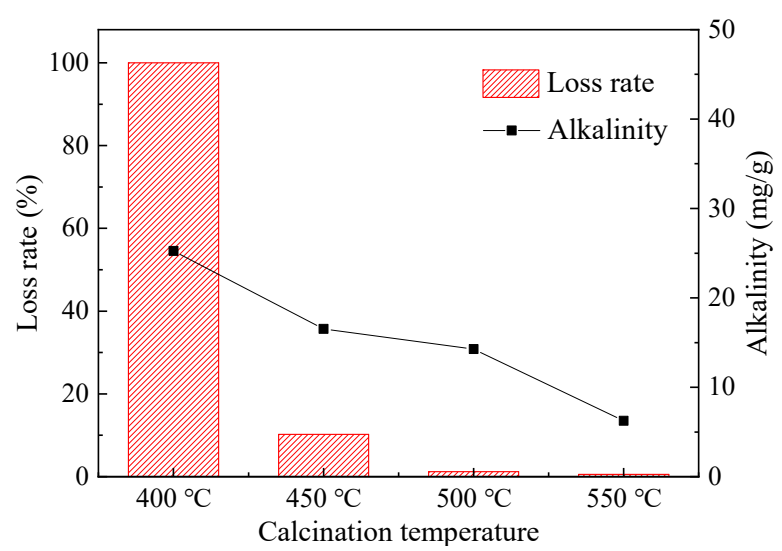

(e)

Figure 5. Adsorption effect of heavy metal ions, loss rate, and alkalinity release amount by composite particles with different calcination temperatures. (a) represents the change of $\mathrm{Pb}$ (II) adsorption quantity with time. (b) represents the change of $\mathrm{Cd}(\mathrm{II})$ adsorption quantity with time. (c) represents the change of $\mathrm{Cr}$ (III) adsorption quantity with time. (d) represents the adsorption quantity by composite particles with different calcination temperatures at $120 \mathrm{~min}$. (e) represents the alkalinity release amount and loss rate by composite particles with different calcination temperatures at $120 \mathrm{~min}$.

The surface water of the composite particles, the internal bound water, and some impurities in the pores were removed by calcination at high temperature. This reduced the effect of the water film resistance on the adsorption, so the adsorption increased. The surface of the uncalcined particles had water molecules, and the water did not evaporate and disperse. Thus, the particles had fewer 
internal channels and surface pores. Composite particles without calcination or with a low calcination temperature $\left(400^{\circ} \mathrm{C}\right)$ were easily pulverized in the aqueous solution and did not achieve the required strength. Increasing the calcination temperature increased the adhesiveness of the silicate compound formed by $\mathrm{Na}_{2} \mathrm{CO}_{3}, \mathrm{SiO}_{2}$, and $\mathrm{Al}_{2} \mathrm{O}_{3}$, and the mechanical strength of the particles increased. However, when the calcination temperature was too high $\left(550{ }^{\circ} \mathrm{C}\right)$, the evaporation and decomposition were exacerbated. Moisture in the montmorillonite structure was removed, the structure was destroyed and collapsed, and the layered structure disappeared. This reduced the internal specific surface area, which decreased the adsorption quantity $[48,49]$. The destruction of the montmorillonite structure made the release of alkalinity difficult, which degraded the synergistic adsorption-coagulation effect. When the temperature was lower than $550{ }^{\circ} \mathrm{C}$, the surface water and water in the pores were mainly lost, and $\mathrm{Na}_{2} \mathrm{CO}_{3}$ decomposed into $\mathrm{CO}_{2}$. The water vapor and $\mathrm{CO}_{2}$ were discharged, which left pores and channels inside and on the surface of the composite particles. The channels and voids provided more adsorption sites for heavy metal ions, which provided more channels for alkalinity release and facilitated the removal of heavy metal ions. In conclusion, the optimum calcination temperature was determined to be $500{ }^{\circ} \mathrm{C}$.

\subsubsection{Determination of the Calcination Time}

To determine the calcination time, the bentonite-steel slag proportion was 5:5, the $\mathrm{Na}_{2} \mathrm{CO}_{3}$ content was $5 \%$, the aging time was $12 \mathrm{~h}$, the calcination particle size was $2 \mathrm{~mm}$, and the calcination temperature was $500^{\circ} \mathrm{C}$. Different composite particles were produced with calcination times of $40 \mathrm{~min}, 60 \mathrm{~min}$, $90 \mathrm{~min}$, and $120 \mathrm{~min}$. Figure 6 shows the results for the adsorption amount, alkalinity release amount, and loss rate. Increasing the calcination time reduced the adsorption effect, speed, and amount. Composite particles with a calcination time of $120 \mathrm{~min}$ adsorbed $4.35 \mathrm{mg} / \mathrm{g}, 4.44 \mathrm{mg} / \mathrm{g}$, and $3.56 \mathrm{mg} / \mathrm{g}$ of $\mathrm{Pb}(\mathrm{II}), \mathrm{Cd}(\mathrm{II})$, and $\mathrm{Cr}(\mathrm{III})$, respectively, so the adsorption effect was not satisfactory. Composite particles with a calcination time of $90 \mathrm{~min}$ adsorbed $4.82 \mathrm{mg} / \mathrm{g}, 4.67 \mathrm{mg} / \mathrm{g}$, and $3.76 \mathrm{mg} / \mathrm{g}$ of Pb(II), $\mathrm{Cd}(\mathrm{II})$, and $\mathrm{Cr}(\mathrm{III})$, respectively, so the adsorption of $\mathrm{Cr}(\mathrm{III})$ was not satisfactory. Composite particles with calcination times of $40 \mathrm{~min}$ and $60 \mathrm{~min}$ adsorbed more than $4.82 \mathrm{mg} / \mathrm{g}$ of $\mathrm{Pb}$ (II), $\mathrm{Cd}(\mathrm{II})$, and $\mathrm{Cr}(\mathrm{III})$, so the removal effect was excellent. As the calcination time increased, both the loss rate and alkalinity release amount decreased. Composite particles with calcination times of $40 \mathrm{~min}, 60 \mathrm{~min}, 90 \mathrm{~min}$, and $120 \mathrm{~min}$ had loss rates of $2.14 \%, 0.88 \%, 0.65 \%$, and $0.44 \%$, respectively. Composite particles with a calcination time of $40 \mathrm{~min}$ had a loss rate more than twice that of particles with a calcination time of $60 \mathrm{~min}$. Composite particles with calcination times of $40 \mathrm{~min}, 60 \mathrm{~min}, 90 \mathrm{~min}$, and $120 \mathrm{~min}$ had alkalinity release amounts of $16.52 \mathrm{mg} / \mathrm{g}, 14.26 \mathrm{mg} / \mathrm{g}, 13.51 \mathrm{mg} / \mathrm{g}$, and $11.01 \mathrm{mg} / \mathrm{g}$, respectively. As the calcination time increased, $\mathrm{Na}_{2} \mathrm{CO}_{3}$ decomposed and released $\mathrm{CO}_{2}$, while the water evaporated continuously. A large amount of $\mathrm{CO}_{2}$ and water vapor overflow increased the internal pore size, and the internal specific surface area decreased, which reduced the adsorption performance. Long calcination times caused a sufficient reaction between $\mathrm{Na}_{2} \mathrm{CO}_{3}$ and $\mathrm{Si}$ and $\mathrm{Al}$ oxides, so the amount of silicate compound formed satisfied the requirements for particle cementation [50]. As the particle strength increased, the loss rate decreased; however, increasing the calcination time made it more difficult to release the alkalinity. In conclusion, the optimum calcination time was $60 \mathrm{~min}$. 


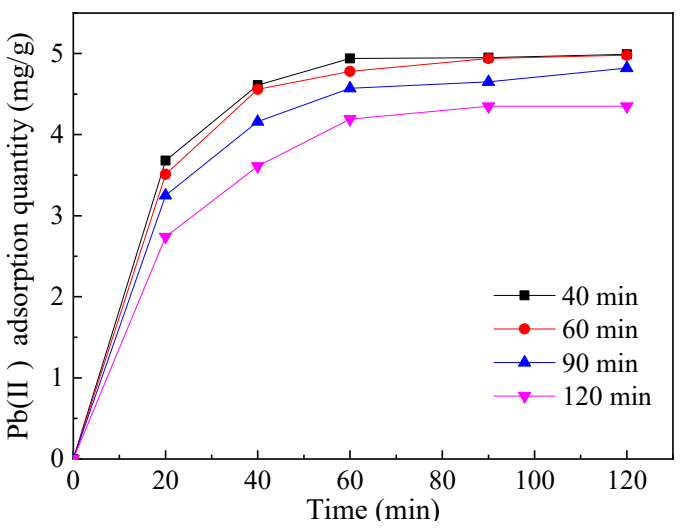

(a)

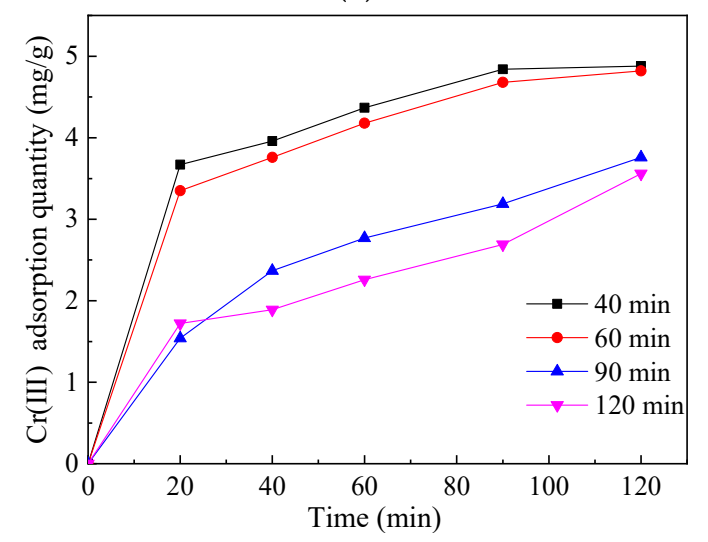

(c)

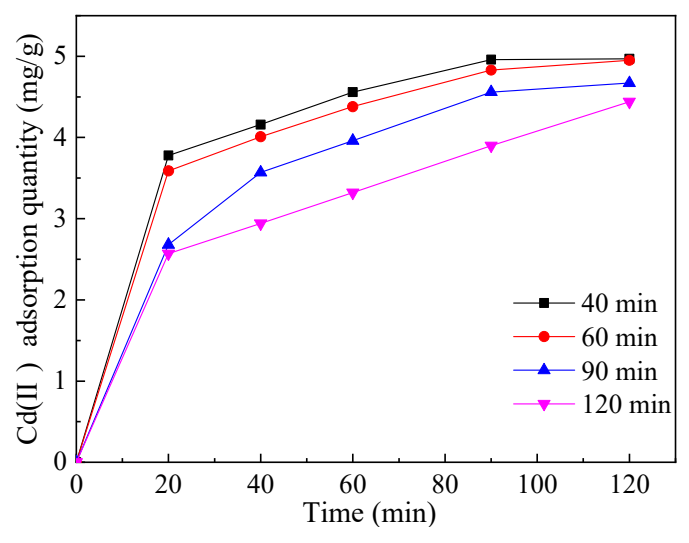

(b)

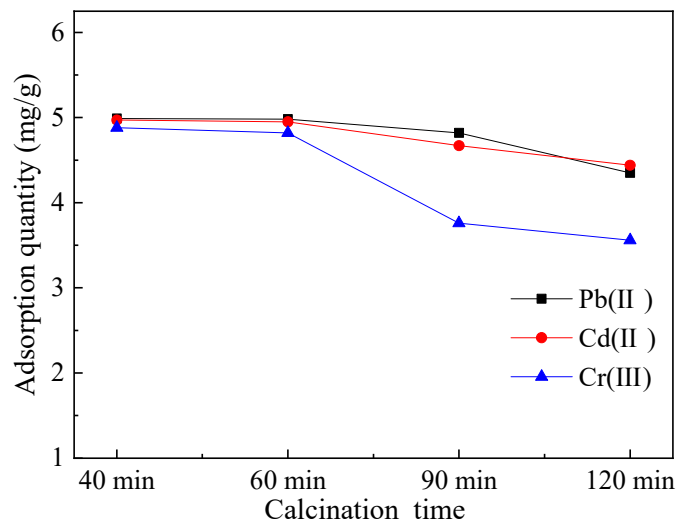

(d)

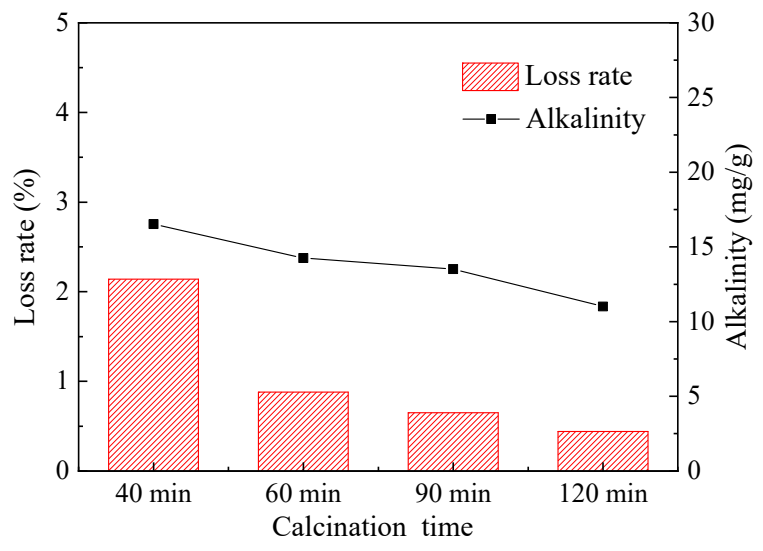

(e)

Figure 6. Adsorption effect of heavy metal ions, loss rate, and alkalinity release amount by composite particles with different calcination times. (a) represents the change of $\mathrm{Pb}$ (II) adsorption quantity with time. (b) represents the change of $\mathrm{Cd}(\mathrm{II})$ adsorption quantity with time. (c) represents the change of $\mathrm{Cr}$ (III) adsorption quantity with time. (d) represents the adsorption quantity by composite particles with different calcination times at $120 \mathrm{~min}$. (e) represents the alkalinity release amount and loss rate by composite particles with different calcination times at $120 \mathrm{~min}$.

\subsection{Orthogonal Experimental Study}

The orthogonal experimental design and results are shown in Table 3. 
Table 3. Orthogonal experiment design and results.

\begin{tabular}{|c|c|c|c|c|c|c|c|c|c|}
\hline \multirow{2}{*}{ Encoding } & \multirow{2}{*}{$\begin{array}{l}\text { Proportion } \\
\text { (Bentonite: } \\
\text { Steel Slag) }\end{array}$} & \multirow{2}{*}{$\begin{array}{c}\mathrm{Na}_{2} \mathrm{CO}_{3} \\
\text { Content } \\
(\%) \\
\end{array}$} & \multirow{2}{*}{$\begin{array}{l}\text { Calcination } \\
\text { Temperature } \\
\left({ }^{\circ} \mathrm{C}\right)\end{array}$} & \multirow{2}{*}{$\begin{array}{l}\text { Calcination } \\
\text { Time } \\
\text { (min) }\end{array}$} & \multicolumn{3}{|c|}{ Adsorption Quantity (mg/g) } & \multirow{2}{*}{$\begin{array}{l}\text { Alkalinity } \\
(\mathrm{mg} / \mathrm{g})\end{array}$} & \multirow{2}{*}{$\begin{array}{c}\text { Loss } \\
\text { Rate } \\
(\%)\end{array}$} \\
\hline & & & & & $\mathrm{Pb}(\mathrm{II})$ & $\mathrm{Cd}(\mathrm{II})$ & Cr(III) & & \\
\hline $\mathrm{A}_{1} \mathrm{~B}_{1} \mathrm{C}_{1} \mathrm{D}_{1}$ & $7: 3$ & 3 & 450 & 40 & 4.19 & 4.09 & 3.99 & 13.16 & 100 \\
\hline $\mathrm{A}_{1} \mathrm{~B}_{2} \mathrm{C}_{2} \mathrm{D}_{2}$ & $7: 3$ & 5 & 500 & 60 & 3.12 & 2.67 & 2.56 & 9.02 & 1.79 \\
\hline $\mathrm{A}_{1} \mathrm{~B}_{3} \mathrm{C}_{3} \mathrm{D}_{3}$ & $7: 3$ & 8 & 550 & 90 & 1.82 & 2.35 & 2.22 & 8.15 & 1.21 \\
\hline $\mathrm{A}_{2} \mathrm{~B}_{1} \mathrm{C}_{2} \mathrm{D}_{3}$ & $6: 4$ & 3 & 500 & 90 & 2.29 & 2.51 & 2.45 & 9.01 & 1.75 \\
\hline $\mathrm{A}_{2} \mathrm{~B}_{2} \mathrm{C}_{3} \mathrm{D}_{1}$ & $6: 4$ & 5 & 550 & 40 & 2.27 & 3.14 & 3.34 & 9.58 & 1.19 \\
\hline $\mathrm{A}_{2} \mathrm{~B}_{3} \mathrm{C}_{1} \mathrm{D}_{2}$ & $6: 4$ & 8 & 450 & 60 & 4.06 & 3.69 & 3.55 & 13.94 & 7.01 \\
\hline $\mathrm{A}_{3} \mathrm{~B}_{1} \mathrm{C}_{3} \mathrm{D}_{2}$ & $5: 5$ & 3 & 550 & 60 & 2.67 & 2.94 & 2.78 & 10.14 & 0.87 \\
\hline $\mathrm{A}_{3} \mathrm{~B}_{2} \mathrm{C}_{1} \mathrm{D}_{3}$ & $5: 5$ & 5 & 450 & 90 & 3.82 & 3.92 & 3.82 & 14.04 & 3.82 \\
\hline $\mathrm{A}_{3} \mathrm{~B}_{3} \mathrm{C}_{2} \mathrm{D}_{1}$ & $5: 5$ & 8 & 500 & 40 & 3.31 & 3.51 & 3.55 & 12.26 & 2.62 \\
\hline
\end{tabular}

Note: A represents proportion (bentonite: steel slag). B represents $\mathrm{Na}_{2} \mathrm{CO}_{3}$ content. C represents calcination temperature. D represents calcination time.

Range Analysis of Orthogonal Experimental Results

Range analysis was performed to examine the results for the five indices: the $\mathrm{Pb}(\mathrm{II}), \mathrm{Cd}(\mathrm{II})$, and $\mathrm{Cr}(\mathrm{III})$ adsorption amounts (the larger the better), alkalinity release amount (the larger the better), and loss rate (the smaller the better). The optimum level and rank of dominant factors for each index were determined. Tables 4 and 5 present the results. The optimum level combinations for the $\mathrm{Pb}(\mathrm{II})$, $\mathrm{Cd}(\mathrm{II})$, and $\mathrm{Cr}(\mathrm{III})$ adsorption amounts were $\mathrm{A}_{3} \mathrm{~B}_{2} \mathrm{C}_{1} \mathrm{D}_{2}, \mathrm{~A}_{3} \mathrm{~B}_{2} \mathrm{C}_{1} \mathrm{D}_{1}$, and $\mathrm{A}_{3} \mathrm{~B}_{2} \mathrm{C}_{1} \mathrm{D}_{1}$, respectively. The optimum level combination for the alkalinity release amount was $A_{3} B_{3} C_{1} D_{1}$, and the optimum level combination for the loss rate was $\mathrm{A}_{3} \mathrm{~B}_{2} \mathrm{C}_{3} \mathrm{D}_{3}$. Because the optimum level combinations of the five indices were inconsistent, the optimum conditions needed to be considered comprehensively according to the order of the factors of the five indices. 
Table 4. Range analysis of adsorption quantity.

\begin{tabular}{|c|c|c|c|c|c|c|c|c|c|c|c|c|}
\hline \multirow[b]{2}{*}{ k Value } & \multicolumn{4}{|c|}{$\mathrm{Pb}(\mathrm{II})$ Adsorption Quantity } & \multicolumn{4}{|c|}{ Cd(II) Adsorption Quantity } & \multicolumn{4}{|c|}{ Cr(III) Adsorption Quantity } \\
\hline & Proportion & $\begin{array}{l}\mathrm{Na}_{2} \mathrm{CO}_{3} \\
\text { Content }\end{array}$ & $\begin{array}{l}\text { Calcination } \\
\text { Temperature }\end{array}$ & $\begin{array}{l}\text { Calcination } \\
\text { Time }\end{array}$ & Proportion & $\begin{array}{l}\mathrm{Na}_{2} \mathrm{CO}_{3} \\
\text { Content }\end{array}$ & $\begin{array}{l}\text { Calcination } \\
\text { Temperature }\end{array}$ & $\begin{array}{l}\text { Calcination } \\
\text { Time }\end{array}$ & Proportion & $\begin{array}{l}\mathrm{Na}_{2} \mathrm{CO}_{3} \\
\text { Content }\end{array}$ & $\begin{array}{l}\text { Calcination } \\
\text { Temperature }\end{array}$ & $\begin{array}{l}\text { Calcination } \\
\text { Time }\end{array}$ \\
\hline $\mathrm{k}_{1}$ & 3.04 & 3.05 & 4.02 & 3.26 & 3.04 & 3.18 & 3.90 & 3.58 & 2.92 & 3.07 & 3.79 & 3.63 \\
\hline $\mathrm{k}_{2}$ & 2.87 & 3.07 & 2.91 & 3.28 & 3.11 & 3.24 & 2.90 & 3.10 & 3.11 & 3.24 & 2.85 & 2.96 \\
\hline $\mathrm{k}_{3}$ & 3.27 & 3.06 & 2.25 & 2.64 & 3.46 & 3.18 & 2.81 & 2.93 & 3.38 & 3.11 & 2.78 & 2.83 \\
\hline $\mathrm{R}$ & 0.40 & 0.02 & 1.77 & 0.64 & 0.42 & 0.06 & 1.09 & 0.65 & 0.46 & 0.17 & 1.01 & 0.80 \\
\hline $\begin{array}{l}\text { optimum } \\
\text { level }\end{array}$ & $5: 5$ & $5 \%$ & $450^{\circ} \mathrm{C}$ & $60 \mathrm{~min}$ & $5: 5$ & $5 \%$ & $450^{\circ} \mathrm{C}$ & $40 \mathrm{~min}$ & $5: 5$ & $5 \%$ & $450^{\circ} \mathrm{C}$ & $40 \mathrm{~min}$ \\
\hline $\begin{array}{l}\text { Dominant } \\
\text { factors } \\
\text { rank }\end{array}$ & \multicolumn{4}{|c|}{$\begin{array}{l}\text { (1) Calcination temperature } \\
\text { (2) Calcination time } \\
\text { (3) Proportion } \\
\text { (4) } \mathrm{Na}_{2} \mathrm{CO}_{3} \text { content }\end{array}$} & \multicolumn{4}{|c|}{$\begin{array}{l}\text { (1) Calcination temperature } \\
\text { (2) Calcination time } \\
\text { (3) Proportion } \\
\text { (4) } \mathrm{Na}_{2} \mathrm{CO}_{3} \text { content }\end{array}$} & \multicolumn{4}{|c|}{$\begin{array}{l}\text { (1) Calcination temperature } \\
\text { (2) Calcination time } \\
\text { (3) Proportion } \\
\text { (4) } \mathrm{Na}_{2} \mathrm{CO}_{3} \text { content }\end{array}$} \\
\hline
\end{tabular}

Table 5. Range analysis of alkalinity and loss rate.

\begin{tabular}{|c|c|c|c|c|c|c|c|c|}
\hline \multirow[b]{2}{*}{$k$ value } & \multicolumn{4}{|c|}{ Alkalinity } & \multicolumn{4}{|c|}{ Loss Rate } \\
\hline & Proportion & $\begin{array}{l}\mathrm{Na}_{2} \mathrm{CO}_{3} \\
\text { Content }\end{array}$ & $\begin{array}{c}\text { Calcination } \\
\text { Temperature }\end{array}$ & $\begin{array}{c}\text { Calcination } \\
\text { Time }\end{array}$ & Proportion & $\begin{array}{l}\mathrm{Na}_{2} \mathrm{CO}_{3} \\
\text { Content }\end{array}$ & $\begin{array}{l}\text { Calcination } \\
\text { Temperature }\end{array}$ & $\begin{array}{c}\text { Calcination } \\
\text { Time }\end{array}$ \\
\hline $\mathrm{k}_{1}$ & 10.11 & 10.77 & 13.71 & 11.67 & 34.33 & 34.21 & 36.94 & 34.6 \\
\hline $\mathrm{k}_{2}$ & 10.84 & 10.88 & 10.10 & 11.03 & 3.32 & 2.27 & 2.05 & 3.22 \\
\hline $\mathrm{k}_{3}$ & 12.15 & 11.45 & 9.29 & 10.40 & 2.44 & 3.61 & 1.09 & 2.26 \\
\hline $\mathrm{R}$ & 2.04 & 0.68 & 4.42 & 1.27 & 31.89 & 31.94 & 35.85 & 32.34 \\
\hline $\begin{array}{c}\text { optimum } \\
\text { level }\end{array}$ & $5: 5$ & $8 \%$ & $450^{\circ} \mathrm{C}$ & $40 \mathrm{~min}$ & $5: 5$ & $5 \%$ & $550^{\circ} \mathrm{C}$ & $90 \mathrm{~min}$ \\
\hline $\begin{array}{l}\text { Dominant } \\
\text { factors } \\
\text { rank }\end{array}$ & \multicolumn{4}{|c|}{$\begin{array}{l}\text { (1) Calcination temperature } \\
\text { (2) Proportion } \\
\text { (3) Calcination time } \\
\text { (4) } \mathrm{Na}_{2} \mathrm{CO}_{3} \text { content }\end{array}$} & \multicolumn{4}{|c|}{$\begin{array}{l}\text { (1) Calcination temperature } \\
\text { (2) Calcination time } \\
\text { (3) } \mathrm{Na}_{2} \mathrm{CO}_{3} \text { content } \\
\text { (4) Proportion }\end{array}$} \\
\hline
\end{tabular}

Note: $\mathrm{k}_{1}$ represents the average adsorbent quantity, alkalinity, and loss rate values of level $7: 3,3 \%, 450{ }^{\circ} \mathrm{C}$, and $40 \mathrm{~min}$. $\mathrm{k}_{2}$ represents the average adsorbent quantity, alkalinity, and loss rate values of level $6: 4,5 \%, 500^{\circ} \mathrm{C}$, and $60 \mathrm{~min} . \mathrm{k}_{3}$ represents the average adsorbent quantity, alkalinity, and loss rate values of level $5: 5,8 \%, 550{ }^{\circ} \mathrm{C}$, and $90 \mathrm{~min}$. R represents the range value, which is the difference between the maximum value of $\mathrm{k}_{1}, \mathrm{k}_{2}, \mathrm{k}_{3}$ and the minimum value of $\mathrm{k}_{1}, \mathrm{k}_{2}, \mathrm{k}_{3}$. Optimum level represents the highest value of $\mathrm{k}_{1}$, $\mathrm{k}_{2}$, $\mathrm{k}_{3}$. Dominant factors rank represents the $\mathrm{R}$ values in descending order. 


\section{Factor A}

The five indices showed no contradiction for the optimum level of factor A. Thus, $\mathrm{A}_{3}$ was selected for factor A.

\section{Factor B}

The five indices were not uniform in the choice of factor B; thus, this factor needed to be considered comprehensively. According to the order of factors, factor B had the fourth-ranked influence on the adsorption amounts of $\mathrm{Pb}(\mathrm{II}), \mathrm{Cd}(\mathrm{II})$, and $\mathrm{Cr}(\mathrm{III})$ and the alkalinity release amounts, so it was a secondary factor. It had the third-ranked influence on the loss rate, so the loss rate was considered first. The optimum level for the loss rate was $\mathrm{B}_{2}$, which was also the optimum level for the $\mathrm{Pb}(\mathrm{II}), \mathrm{Cd}(\mathrm{II})$, and $\mathrm{Cr}(\mathrm{III})$ adsorptions. For the alkalinity release, $\mathrm{B}_{2}$ was only beaten by $\mathrm{B}_{3}$, so it could also achieve a good alkalinity release effect. In conclusion, $B_{2}$ was selected for factor $B$.

\section{Factor C}

Factor $\mathrm{C}$ had the first-ranked influence on all five indices. The optimum level of the $\mathrm{Pb}(\mathrm{II}), \mathrm{Cd}(\mathrm{II})$, and $\mathrm{Cr}(\mathrm{III})$ adsorptions and the alkalinity release was $\mathrm{C}_{1}$. The optimum level of the loss rate was $C_{3}$. Thus, $C_{1}$ should generally be selected. However, the loss rate had a much larger $k_{1}$ value than the $k_{2}$ and $\mathrm{k}_{3}$ values, which means that the loss rate would be large with $\mathrm{C}_{1}$ and the strength requirement cannot be met. Thus, $\mathrm{C}_{1}$ was excluded. If $\mathrm{C}_{3}$ was selected, the $\mathrm{Pb}$ (II), $\mathrm{Cd}(\mathrm{II})$, and $\mathrm{Cr}$ (III) adsorption amounts and alkalinity amount would be the lowest. Thus, $\mathrm{C}_{3}$ was excluded. Thus, $\mathrm{C}_{2}$ was selected for factor $\mathrm{C}$, so that good results would be achieved for all five indices.

\section{Factor D}

Factor D had the third-ranked effect on the alkalinity release quantity, and second-ranked influence on the other four indices. First, the adsorption amounts of $\mathrm{Pb}$ (II), $\mathrm{Cd}$ (II), and $\mathrm{Cr}$ (III) and the loss rate were considered. The optimum levels were $\mathrm{D}_{2}$ for the $\mathrm{Pb}$ (II) adsorption amount, $\mathrm{D}_{1}$ for the $\mathrm{Cd}(\mathrm{II})$ and $\mathrm{Cr}(\mathrm{III})$ adsorption amounts, and $\mathrm{D}_{3}$ for the loss rate. Generally, $\mathrm{D}_{1}$ should be selected. However, the loss rate with $\mathrm{D}_{1}$ was too high to meet the strength requirement, so $\mathrm{D}_{1}$ was excluded. Second, the adsorption amounts of $\mathrm{Pb}(\mathrm{II}), \mathrm{Cd}(\mathrm{II})$, and $\mathrm{Cr}(\mathrm{III})$ were lowest at $\mathrm{D}_{3}$, so $\mathrm{D}_{3}$ was also excluded. Finally, since the values of $k_{2}$ and $k_{3}$ of the loss rate were not much different from each other and were far less than the $\mathrm{k}_{1}$ value, and the amounts of $\mathrm{Pb}(\mathrm{II}), \mathrm{Cd}(\mathrm{II})$, and $\mathrm{Cr}(\mathrm{III})$ adsorption and alkalinity release at $\mathrm{D}_{2}$ were second only to the optimum level, $\mathrm{D}_{2}$ was selected for factor $\mathrm{D}$.

The optimum process conditions for the orthogonal experiment were finally determined to be $\mathrm{A}_{3} \mathrm{~B}_{2} \mathrm{C}_{2} \mathrm{D}_{2}$. This converts to a bentonite-steel slag proportion of 5:5, $\mathrm{Na}_{2} \mathrm{CO}_{3}$ content of $5 \%$, calcination temperature of $500{ }^{\circ} \mathrm{C}$, and calcination time of $60 \mathrm{~min}$. Based on the single-factor experimental results, the aging time was set to $12 \mathrm{~h}$, and the calcination particle size was set to $2 \mathrm{~mm}$. Finally, a verification test was carried out under the above optimum process conditions. The adsorption amounts of $\mathrm{Pb}(\mathrm{II})$, $\mathrm{Cd}(\mathrm{II})$, and $\mathrm{Cr}$ (III) were $4.98 \mathrm{mg} / \mathrm{g}, 4.95 \mathrm{mg} / \mathrm{g}$, and $4.86 \mathrm{mg} / \mathrm{g}$, respectively. The alkalinity release amount was $14.28 \mathrm{mg} / \mathrm{g}$, and the loss rate was $0.86 \%$. These were the best values among the test results, so the optimum process conditions were successfully verified.

The optimum preparation process for BSC was determined via single-factor and orthogonal experiments. The simulated AMD with an initial concentration of $\mathrm{Pb}(\mathrm{II}), \mathrm{Cd}(\mathrm{II})$, and $\mathrm{Cr}$ (III) of $50 \mathrm{mg} / \mathrm{L}$ and initial PH from 3.0 to 3.5 was treated with the optimum BSC. After treatment, the ion removal effect was more than $97 \%$, the $\mathrm{PH}$ of the solution was from 6.5 to 8.5 , and the particles were easy to separate. Thus, it is an excellent and cheap adsorbent that can be used for the treatment of AMD with heavy metal ions. 


\subsection{Adsorption Isotherms}

The Langmuir, Freundlich, Dubinin-Radushkevich (D-R), and Brunauer-Emmett-Teller (BET) models were used to analyze the experimental data to explain the adsorption mechanism of $\mathrm{Pb}(\mathrm{II})$ on BSC.

The Langmuir isotherm model [51] can be expressed as follows:

$$
\frac{C_{e}}{q_{e}}=\frac{1}{b q_{m}}+\frac{C_{e}}{q_{m}}
$$

where $C_{e}$ is the equilibrium solute concentration $(\mathrm{mg} / \mathrm{L}), q_{e}$ is the adsorption amount at equilibrium $(\mathrm{mg} / \mathrm{g}), q_{m}$ is the monolayer saturation capacity $(\mathrm{mg} / \mathrm{g})$, and $\mathrm{b}$ is the Langmuir constant $(\mathrm{L} / \mathrm{mg})$.

The Freundlich isotherm model can be expressed as follows:

$$
\ln q_{e}=\ln K_{F}+\frac{1}{n} \ln C_{e}
$$

where $C_{e}$ and $q_{e}$ are defined in the same manner as in Equation (8), $K_{F}$ is the Freundlich constant $(\mathrm{L} / \mathrm{g})$ indicating the adsorption capacity, and $n$ is the isotherm constant indicating the adsorption intensity.

The D-R model can be expressed as follows:

$$
\ln q_{e}=\ln q_{m}-k \varepsilon^{2}
$$

where $q_{m}$ is the monolayer saturation capacity $(\mathrm{mol} / \mathrm{g}), k$ is the model constant of adsorption energy $\left(\mathrm{mol}^{2} / \mathrm{kJ}^{2}\right)$, and $\varepsilon$ is the Polanyi potential, which is given by:

$$
\varepsilon=R \operatorname{Tln}\left(1+\frac{1}{C_{e}}\right)
$$

where the unit for $E$ should in $\mathrm{mol} / \mathrm{L}$.

The mean free energy of adsorption $E$ is:

$$
E=-\frac{1}{\sqrt{2 k}}
$$

The BET model can be expressed as follows:

$$
\frac{C_{e}}{\left(C_{s}-C_{e}\right) q_{e}}=\frac{1}{B q_{0}}+\frac{B-1}{B q_{0}} \frac{C_{e}}{C_{s}}
$$

where $C_{e}$ and $q_{e}$ are defined in the same manner as in Equation (8), $q_{0}$ is the monolayer saturation capacity $(\mathrm{g} / \mathrm{g}), C_{s}$ is the saturated concentration of the adsorbate $(\mathrm{g} / \mathrm{L})$, and $B$ is the BET constant.

It can be seen from Table 6 that the fitting effect of the four isothermal models is good, and the correlation coefficients of Langmuir and BET models are relatively high, indicating that the Langmuir and BET models are more suitable to describe the isothermal adsorption process than the other models. It should be noted that the adsorption of heavy metal ions by bentonite satisfied the Langmuir model. In addition, the alkalinity released by BSC reacted with $\mathrm{Pb}(\mathrm{II}), \mathrm{Cd}(\mathrm{II})$, and $\mathrm{Cr}$ (III) to form a hydroxide, which accumulated layer by layer on BSC, which continued to adsorb $\mathrm{Pb}$ (II), $\mathrm{Cd}(\mathrm{II})$, and $\mathrm{Cr}$ (III). A synergistic adsorption-coagulation effect occurred, leading to the appearance of multiple layers locally on the surface of BSC, which satisfied the BET model. For Pb(II), Cd(II), and $\mathrm{Cr}(\mathrm{III})$ adsorption by BSC, the monolayer saturated adsorption capacities calculated via the Langmuir isothermal model were $53.53 \mathrm{mg} / \mathrm{g}$, $28.97 \mathrm{mg} / \mathrm{g}$, and $17.81 \mathrm{mg} / \mathrm{g}$, respectively, which was, in essence, the same as that calculated using the BET model. The adsorption of $\mathrm{Pb}(\mathrm{II}), \mathrm{Cd}(\mathrm{II})$, and $\mathrm{Cr}(\mathrm{III})$ on BSC satisfied the BET model. 
Table 6. Isothermal constants for the adsorption of $\mathrm{Pb}(\mathrm{II}), \mathrm{Cd}(\mathrm{II})$, and $\mathrm{Cr}(\mathrm{III})$ onto bentonite-steel slag composite particles (BSC).

\begin{tabular}{cccc}
\hline Isothermal Models & $\mathbf{P b}(\mathrm{II})$ & $\mathbf{C d}(\mathbf{I I})$ & $\mathbf{C r}(\mathbf{I I I})$ \\
\hline Langmuir isotherm & & & \\
$q_{m}(\mathrm{mg} / \mathrm{g})$ & 53.53 & 28.97 & 17.81 \\
$b(\mathrm{~L} / \mathrm{mg})$ & 0.0105 & 0.0259 & 0.0154 \\
$R^{2}$ & 0.997 & 0.998 & 0.999 \\
\hline Freundlich isotherm & & & \\
$K_{F}(\mathrm{~L} / \mathrm{g})$ & 1.68 & 1.83 & 0.96 \\
$n$ & 1.69 & 1.91 & 0.98 \\
$R^{2}$ & 0.986 & 0.966 & \\
$\mathrm{D}_{-\mathrm{R} \text { isotherm }}$ & & & 44.32 \\
$q_{m}(\mathrm{mg} / \mathrm{g})$ & 214.69 & 101.89 & 0.0061 \\
$k\left(\mathrm{~mol}^{2} / \mathrm{kJ}\right)^{2}$ & 0.0059 & 0.0053 & -9.01 \\
$E(\mathrm{~kJ} / \mathrm{mol})$ & -9.19 & -9.74 & 0.979 \\
$R^{2}$ & 0.995 & 0.985 & 17.76 \\
\hline $\mathrm{BET}$ isotherm & & & 0.999 \\
$q_{0}(\mathrm{mg} / \mathrm{g})$ & 53.46 & 28.96 & \\
$R^{2}$ & 0.997 & 0.998 & \\
\hline
\end{tabular}

\subsection{Results of Microstructure Characterization}

\subsubsection{SEM and BET Analysis}

Figure 7 shows the SEM image of the raw materials and optimum BSC used in the study. From Figure $7 \mathrm{a}$, it can be seen that there is no layered structure in bentonite, and there are only a few pores on its surface. Steel slag (Figure 7b) has a non-layered, irregular, and loose structure. Before calcination (Figure 7c), water molecules were present in BSC, and the particles had a compact internal structure. However, after calcination, layer formation was visible in optimum BSC (Figure 7d), and its surface was rough and had many pores that were conducive to adsorption. Table 7 shows the textural properties of bentonite, steel slag, BSC before calcination, and optimum BSC. BET adsorption studies show that the specific surface area $\left(S_{B E T}\right)$ of the optimum BSC is $130.6 \mathrm{~m}^{2} / \mathrm{g}$ with an average pore radius of $8.4 \mathrm{~nm}$, and the total pore volume is $5.14 \mathrm{~cm}^{3} / \mathrm{g}$. These values are significantly higher than those of bentonite, steel slag, and uncalcined BSC. Upon calcination of BSC, water evaporates, and $\mathrm{Na}_{2} \mathrm{CO}_{3}$ is decomposed into $\mathrm{CO}_{2}$, resulting in the formation of numerous pores in BSC. This reflects the observed increase in the pore radius, total pore volume, and $S_{B E T}$ values. 


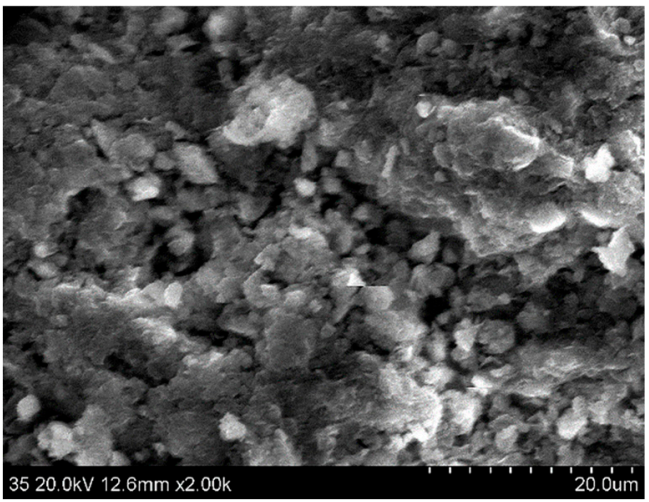

(a)

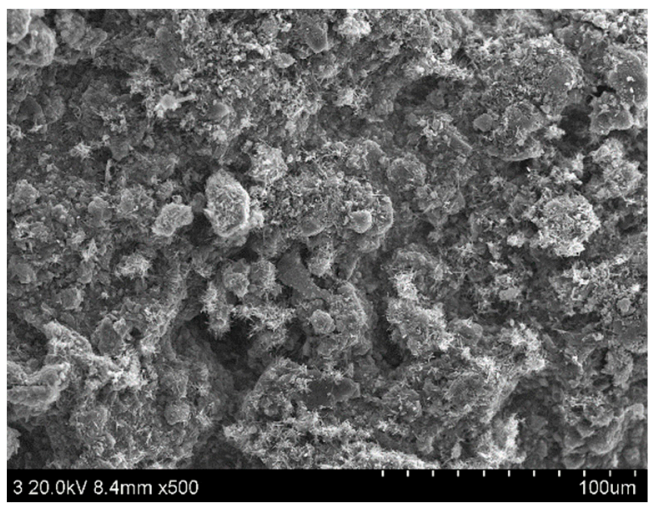

(c)

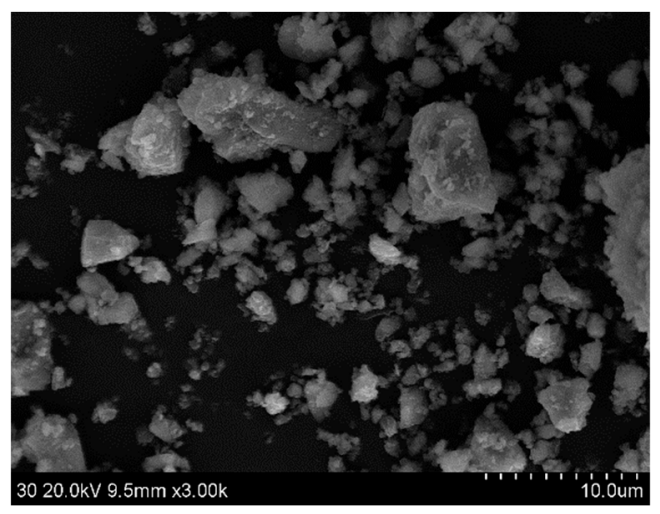

(b)

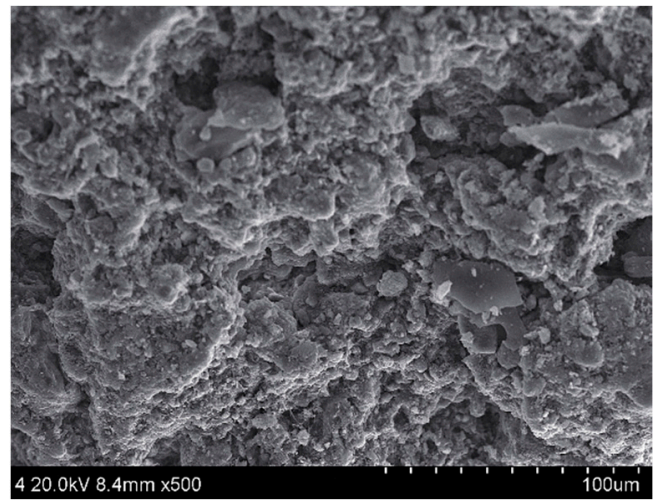

(d)

Figure 7. SEM (scanning electron microscopy) images of (a) bentonite, (b) steel slag, (c) BSC before calcination, and (d) optimum BSC.

Table 7. The textural properties of bentonite, steel slag, BSC before calcination, and optimum BSC.

\begin{tabular}{cccc}
\hline Sample & $\mathbf{S}_{B E T}\left(\mathbf{m}^{2} / \mathbf{g}\right)$ & $\begin{array}{c}\text { Average Pore Radius } \\
(\mathbf{n m})\end{array}$ & $\begin{array}{c}\text { Total Pore Volume } \\
\left(\mathbf{c m}^{\mathbf{3}} / \mathbf{g}\right)\end{array}$ \\
\hline Bentonite & 76.5 & 6.2 & 0.18 \\
Steel slag & 0.4 & 5.3 & 0.06 \\
BSC before calcination & 50.7 & 4.5 & 0.11 \\
Optimum BSC & 130.6 & 8.4 & 5.14 \\
\hline
\end{tabular}

\subsubsection{XRD Analysis}

Figure 8 shows the XRD patterns of bentonite, steel slag, and optimum BSC. The main mineral components of bentonite are montmorillonite, quartz, and feldspar. The bentonite used in this study was sodium bentonite and the spacing between its layers was found to be $\mathrm{d}^{(001)}=1.287 \mathrm{~nm}$. The position of the $\mathrm{d}^{(060)}$ peaks varies for the different types of montmorillonites. When $\mathrm{d}^{(060)}$ is between 0.149 and $0.151 \mathrm{~nm}$, montmorillonite has a dioctahedral structure; whereas if $\mathrm{d}^{(060)}$ is between 0.153 and $0.155 \mathrm{~nm}$, then the crystal structure is trioctahedral. In the XRD pattern of bentonite (Figure 8a) the $\mathrm{d}^{(060)}$ value was $0.1498 \mathrm{~nm}$, this confirms that the montmorillonite had a dioctahedral structure [52]. In steel slag (Figure 8b), $\mathrm{Ca}_{2} \mathrm{SiO}_{4}, \mathrm{Na}_{4} \mathrm{SiO}_{4}$, and $\mathrm{Ca}(\mathrm{OH})_{2}$ are the main mineral components, whereas it is $\mathrm{SiO}_{2}, \mathrm{Ca}_{2} \mathrm{SiO}_{4}, \mathrm{Na}_{2} \mathrm{AlSi}_{3} \mathrm{O}_{8} \mathrm{OH}, \mathrm{NaAlSi}_{2} \mathrm{O}_{6}, \mathrm{NaFeSi}_{2} \mathrm{O}_{6}, \mathrm{Ca}_{3} \mathrm{Fe}_{3}\left(\mathrm{SiO}_{4}\right)_{3}$ for optimum BSC (Figure 8c). The position of the $\mathrm{d}^{(001)}$ peak was found to be $1.549 \mathrm{~nm}$ for the optimum BSC (Figure 8c). This indicates that the layer spacing increased after the composite particles were calcined and modified, and some new substances entered the interlayer of montmorillonite. In optimum BSC, $\mathrm{d}^{(060)}=0.1505 \mathrm{~nm}$ (Figure 8c) and the montmorillonite retained its dioctahedral structure, indicating that the structure of the composite particles did not change after calcination. Upon calcination some minerals remained the 
same, whereas a few new minerals, such as $\mathrm{NaAlSi}_{2} \mathrm{O}_{6}, \mathrm{NaFeSi}_{2} \mathrm{O}_{6}$, and $\mathrm{Ca}_{3} \mathrm{Fe}_{3}\left(\mathrm{SiO}_{4}\right)_{3}$, were generated. The composition of quartz is $\mathrm{SiO}_{2}$ and $\mathrm{Na}_{2} \mathrm{AlSi}_{3} \mathrm{O}_{8} \mathrm{OH}$. Montmorillonite and $\mathrm{Ca}_{2} \mathrm{SiO}_{4}$ are the alkaline phases. The newly formed silicates satisfied the requirements for BSC cementation. Thus, the optimum BSC obtained by calcination retained its dioctahedral structure. Since the layer spacing increased in the optimum BSC, its adsorption performance for heavy metal ions enhanced significantly. Moreover, the presence of alkaline substances in the optimum BSC shows that it has the common characteristics of bentonite and steel slag, which can absorb heavy metal ions and reduce the acidity at the same time.

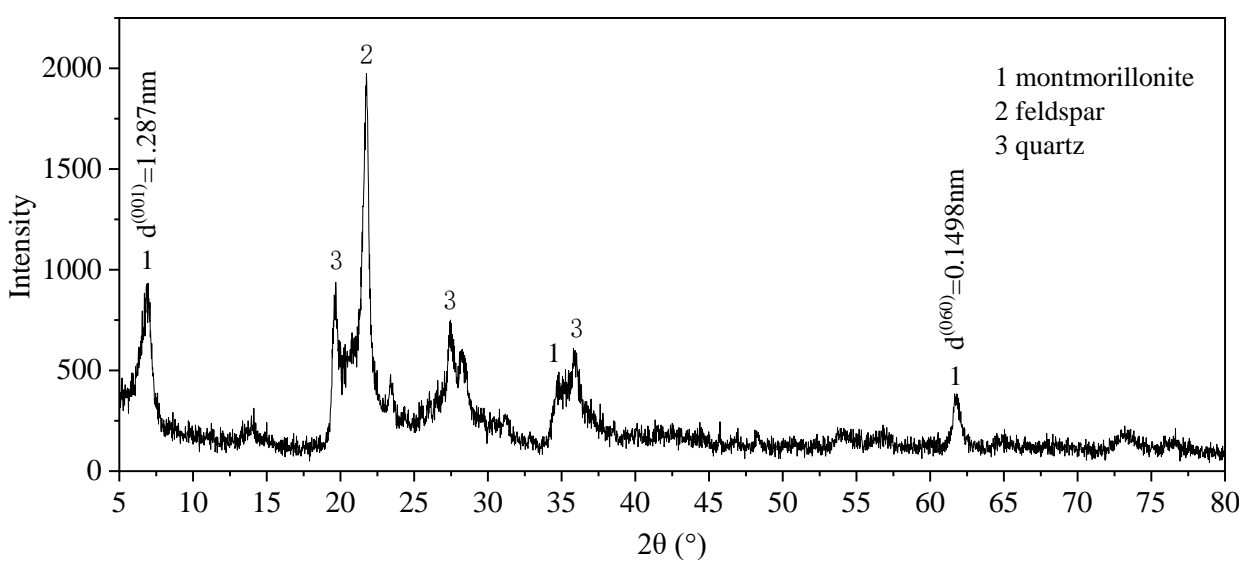

(a)

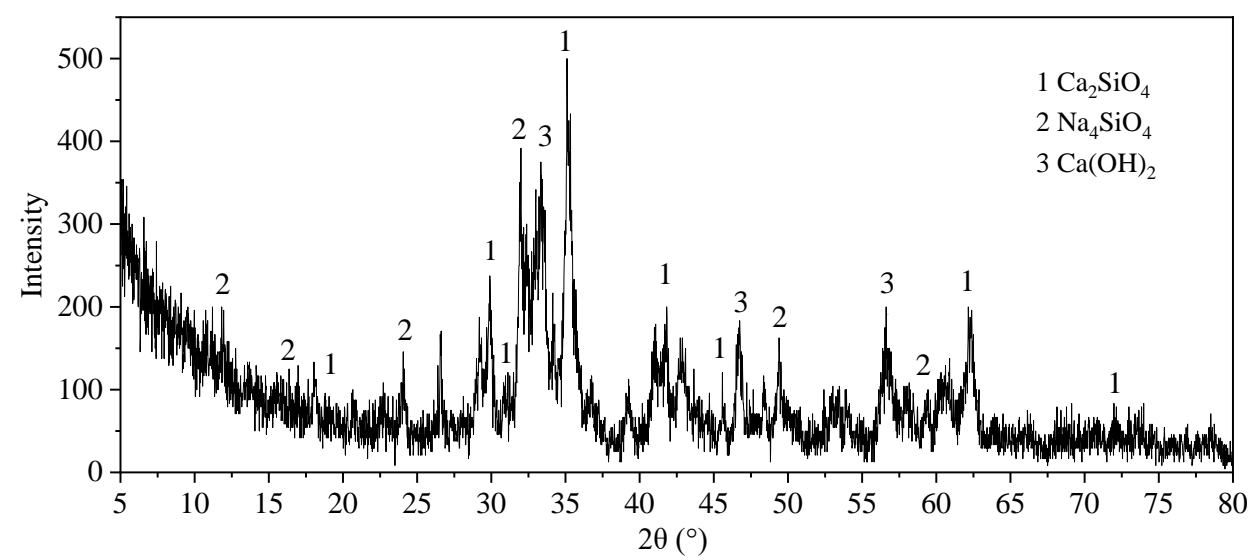

(b)

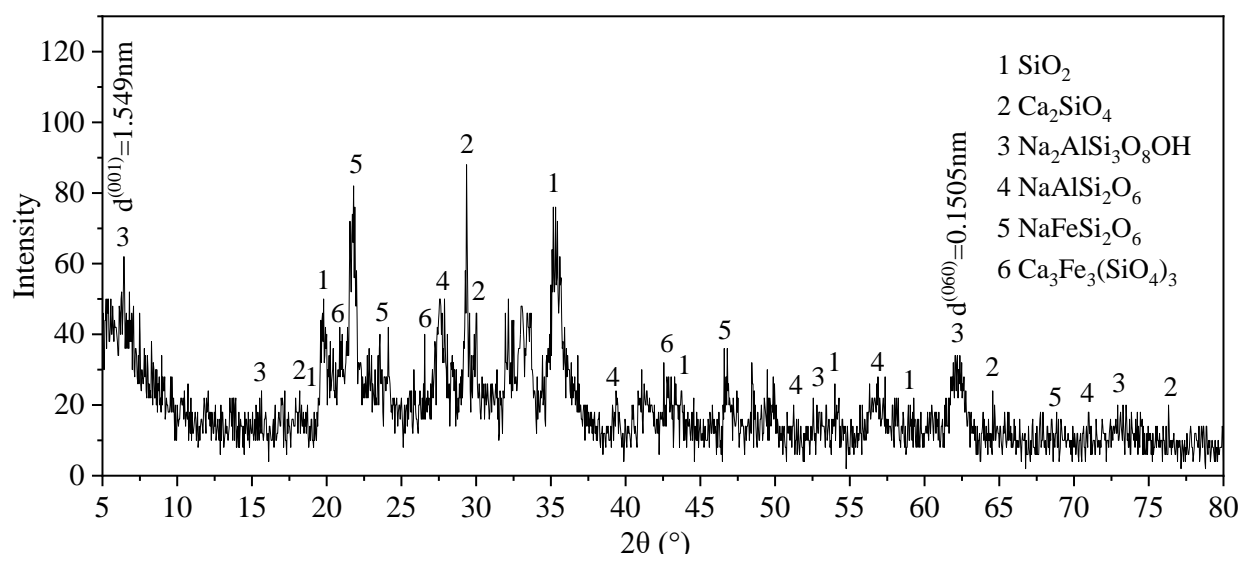

(c)

Figure 8. X-ray powder diffraction (XRD) patterns of (a) bentonite, (b) steel slag, and (c) optimum BSC. 


\subsubsection{FT-IR Analysis}

In the FTIR spectrum of bentonite (Figure 9a), a strong hydroxyl stretching vibration peak (Al-OH) appeared at $3826.94 \mathrm{~cm}^{-1}$. The stretching vibration peak of the hydroxyl group from the adsorbed water between the layers occurred at $3439.84 \mathrm{~cm}^{-1}$, whereas the $\mathrm{H}-\mathrm{O}-\mathrm{H}$ bending vibration peak of the water present between the layers of montmorillonite occurred at $1638.06 \mathrm{~cm}^{-1}$. The Si-O-Si stretching vibration absorption peak near $1040 \mathrm{~cm}^{-1}$ showed two splits at $1087.74 \mathrm{~cm}^{-1}$ and $1037.74 \mathrm{~cm}^{-1}$. This split peak indicates that the montmorillonite layers contained $\mathrm{Na}^{+}$ions [53]. In the FTIR spectrum of steel slag (Figure 9b), the hydroxyl stretching vibration peak of internal water occurred at $3386.32 \mathrm{~cm}^{-1}$, the stretching vibrations and the bending vibrations of Ca-O occurred at $1434.43 \mathrm{~cm}^{-1}$ and $875.42 \mathrm{~cm}^{-1}$, respectively, the remaining peaks corresponded to the vibrations of $\mathrm{Si}-\mathrm{O}$.

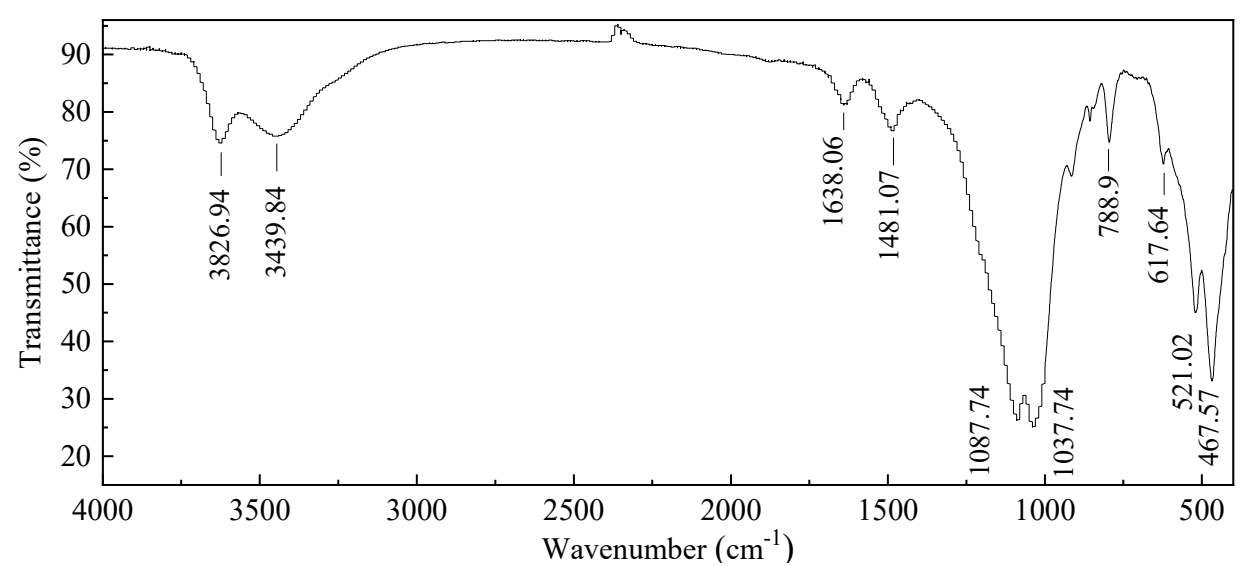

(a)

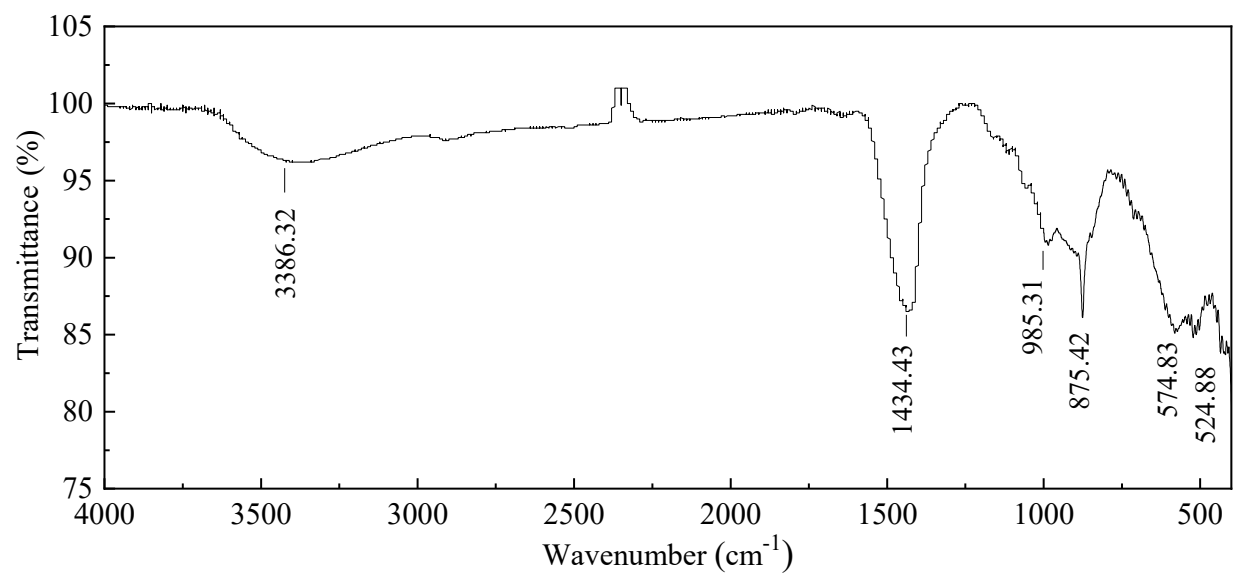

(b)

Figure 9. Cont. 


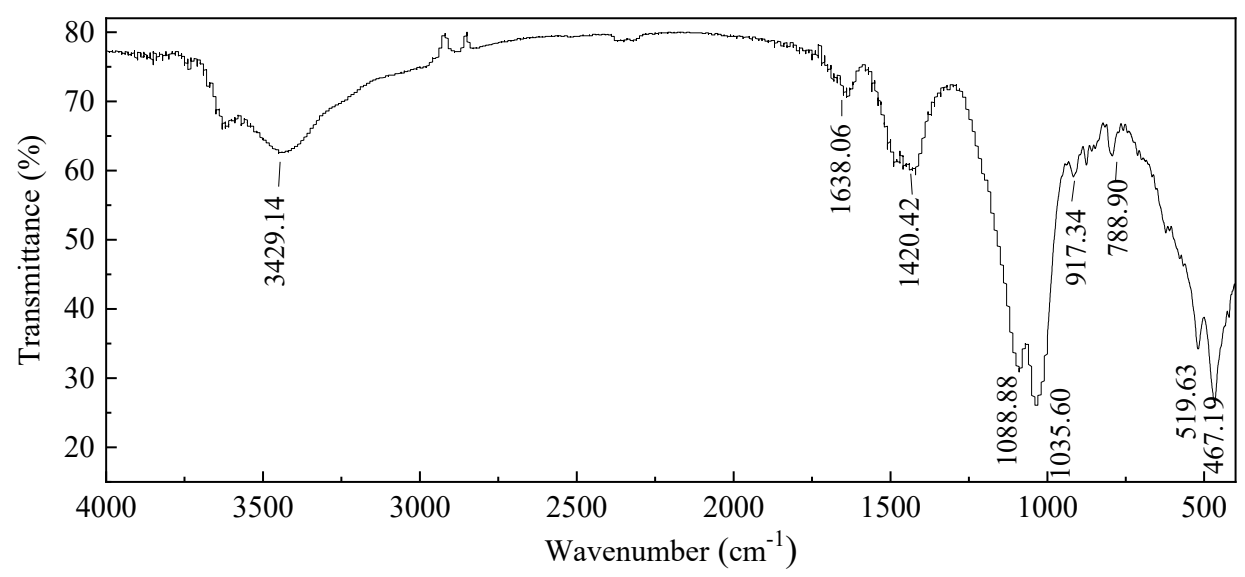

(c)

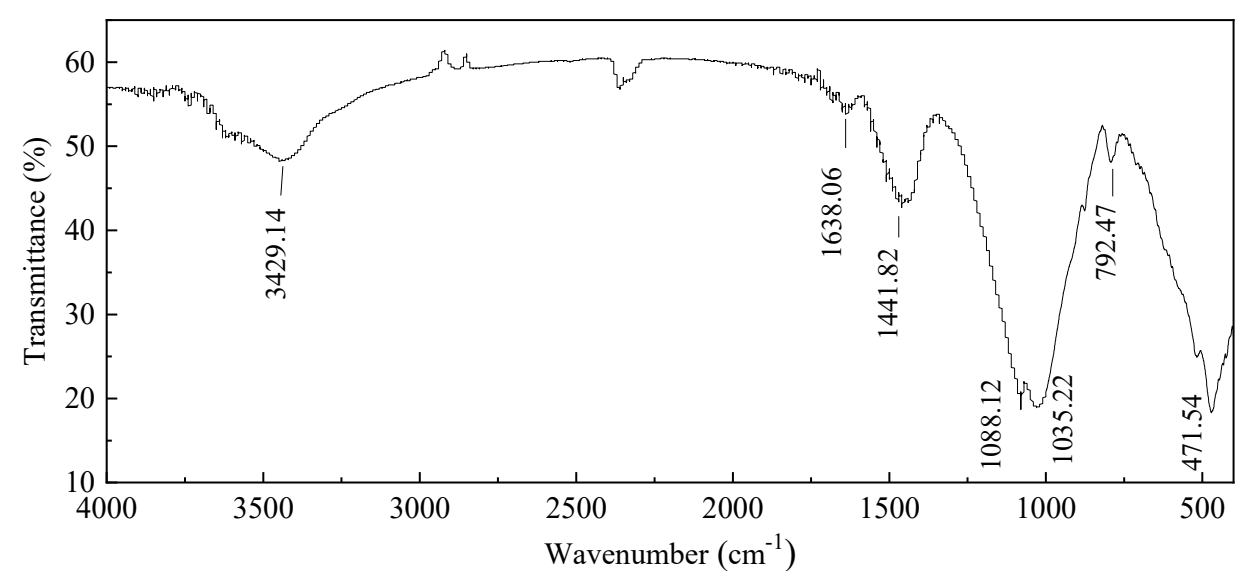

(d)

Figure 9. Fourier-transform infrared spectroscopy (FTIR) spectra of (a) bentonite, (b) steel slag, (c) BSC before calcination, and (d) optimum BSC.

In the infrared spectrum of BSC before calcination (Figure 9c), the hydroxyl stretching vibration of the interlayer water at $3439.84 \mathrm{~cm}^{-1}$ moved to a low frequency of $3429.14 \mathrm{~cm}^{-1}$, indicating that the interlayer water changed. After calcination (Figure 9d), the characteristic peaks of the hydroxyl water at $3429.14 \mathrm{~cm}^{-1}$ and $1638.83 \mathrm{~cm}^{-1}$ became weaker. This implies that calcination removed the water between the layers, making the layer spacing larger. Also, the two split peaks near $1040 \mathrm{~cm}^{-1}$ shifted to $1088.88 \mathrm{~cm}^{-1}$ and $1035.60 \mathrm{~cm}^{-1}$. This was attributed to the reaction of the components in steel slag with the interlayer $\mathrm{Na}^{+}$of montmorillonite. After calcination, the bimodal peaks still existed, suggesting the presence of exchangeable $\mathrm{Na}^{+}$in the interlayers. Before calcination, the characteristic absorption peaks of $\mathrm{Si}-\mathrm{O}$ and $\mathrm{Al}-\mathrm{O}$ in the montmorillonite structure were between 1000 and $450 \mathrm{~cm}^{-1}$. The coupled vibration absorption of $\mathrm{M}-\mathrm{O}$ formed by metal ions with oxygen was also present in the spectrum. After calcination, only the Si-O stretching vibration absorption peak near $792.47 \mathrm{~cm}^{-1}$ and $\mathrm{Si}-\mathrm{O}$ bending vibration absorption peak near $471.54 \mathrm{~cm}^{-1}$ were obvious. Other vibration peaks weakened or disappeared after calcination, due to the removal of the impurities between the layers of montmorillonite.

\section{Conclusions}

The preparation procedure and mechanism for optimizing the BSC were studied thoroughly in this experiment. The single-factor experimental results determined an optimum aging time of $12 \mathrm{~h}$ and optimum calcination particle size of $2 \mathrm{~mm}$. The optimum bentonite-steel slag proportion was 5:5. The 
optimum $\mathrm{Na}_{2} \mathrm{CO}_{3}$ content was $5 \%$. The optimum calcination temperature was $500{ }^{\circ} \mathrm{C}$. The optimum calcination time was $60 \mathrm{~min}$.

Based on the results of the single-factor experiment, an orthogonal experiment was performed. The optimum process conditions for preparing the composite particles were determined by range analysis: a bentonite-steel slag proportion of $5: 5, \mathrm{Na}_{2} \mathrm{CO}_{3}$ amount of $5 \%$ of the total mass, aging time of $12 \mathrm{~h}$ under lightproof conditions, calcination particle size of $2 \mathrm{~mm}$, calcination temperature of $500{ }^{\circ} \mathrm{C}$, and calcination time of $60 \mathrm{~min}$. In terms of the adsorption performance and particle strength, the composite particles under the optimum process conditions performed better than the particles prepared by other processes and were defined as the optimum BSC.

The isothermal adsorption data of the optimum BSC were analyzed using the Langmuir, Freundlich, $\mathrm{D}-\mathrm{R}$, and BET models. The Langmuir and BET models led to the best isotherms. A synergistic adsorption-coagulation effect occurred, leading to the appearance of multiple layers locally on the surface of BSC, which satisfied the BET model.

SEM and BET analysis revealed that after calcination, the surface of the optimum BSC was rough and had a layered structure. The $S_{B E T}$, average pore radius, and the total pore volume were found to be $130.6 \mathrm{~m}^{2} / \mathrm{g}, 8.4 \mathrm{~nm}$, and $5.14 \mathrm{~cm}^{3} / \mathrm{g}$ respectively. From XRD analysis, the optimum BSC layer spacing was calculated to be $1.549 \mathrm{~nm}$, and the dioctahedral structure remained unaltered. Besides this, the XRD pattern showed the presence of both montmorillonite and alkaline substances. The silicates formed satisfied the conditions for BSC cementation. From the FTIR spectrum, exchangeable $\mathrm{Na}^{+}$between the layers of the optimum BSC was detected. Moisture and impurities were removed by calcination.

The optimum BSCs have the synergistic adsorption-coagulation effect and overcome the limitations of a single material, single method, and single function. It is a new multifunctional protective material for mining environments that can simultaneously remove heavy metal ions and reduce acidity. The experimental study reported in this paper provides a new material for treatment of AMD containing heavy metal ions. Quantification of the optimal conditions and factors for AMD remediation by BSC will improve the cost effectiveness of this method. This work will be of broad interest to AMD remediation specialists in the coal and sulfide metal mining sectors.

Author Contributions: Conceptualization, X.Z.; Formal analysis, X.Z.; Funding acquisition, L.X. and B.L.; Investigation, X.Z.; Project administration, L.X.; Writing—original draft, X.Z.; Writing—review and editing, X.Z. All authors have read and agreed to the published version of the manuscript.

Funding: This research received no external funding.

Acknowledgments: This project was funded by the National Natural Science Foundation of China (51474122, 51174267), Key Project of Science and Technology Research of Education Department of Liaoning Province (ZL002) and Millions of Talents Project of Liaoning Province (2014921069).

Conflicts of Interest: The authors declare no conflicts of interest.

\section{References}

1. Akcil, A.; Koldas, S. Acid Mine Drainage (AMD): Causes, treatment and case studies. J. Clean. Prod. 2006, 14, 1139-1145. [CrossRef]

2. Bessho, M.; Wajima, T.; Ida, T.; Nishiyama, T. Experimental study on prevention of acid mine drainage by silica coating of pyrite waste rocks with amorphous silica solution. Environ. Earth Sci. 2011, 64, 311-318. [CrossRef]

3. Kefeni, K.K.; Msagati, T.A.M.; Mamba, B.B. Acid mine drainage: Prevention, treatment options, and resource recovery: A review. J. Clean. Prod. 2017, 151, 475-493. [CrossRef]

4. Rodriguez, C.; Leiva-Aravena, E.; Serrano, J.; Leiva, E. Occurrence and Removal of Copper and Aluminum in a Stream Confluence Affected by Acid Mine Drainage. Water 2018, 10, 516. [CrossRef]

5. Gutierrez, M.; Mickus, K.; Camacho, L.M. Abandoned Pb-Zn mining wastes and their mobility as proxy to toxicity: A review. Sci. Total Environ. 2016, 565, 392-400. [CrossRef] [PubMed] 
6. Oldham, C.; Beer, J.; Blodau, C.; Fleckenstein, J.; Jones, L.; Neumann, C.; Peiffer, S. Controls on iron(II) fluxes into waterways impacted by acid mine drainage: A Damkohler analysis of groundwater seepage and iron kinetics. Water Res. 2019, 153, 11-20. [CrossRef] [PubMed]

7. Balistrieri, L.S.; Seal, R.R.; Piatak, N.M.; Paul, B. Assessing the concentration, speciation, and toxicity of dissolved metals during mixing of acid-mine drainage and ambient river water downstream of the Elizabeth Copper Mine, Vermont, USA. Appl. Geochem. 2007, 22, 930-952. [CrossRef]

8. Beygli, R.A.; Mohaghegh, N.; Rahimi, E. Metal ion adsorption from wastewater by g-C3N4 modified with hydroxyapatite: A case study from Sarcheshmeh Acid Mine Drainage. Res. Chem. Intermediat. 2019, 45, 2255-2268. [CrossRef]

9. Naidu, G.; Ryu, S.; Thiruvenkatachari, R.; Choi, Y.; Jeong, S.; Vigneswaran, S. A critical review on remediation, reuse, and resource recovery from acid mine drainage. Environ. Pollut. 2019, 247, 1110-1124. [CrossRef]

10. Amin, M.T.; Alazba, A.A.; Shafiq, M. Adsorptive Removal of Reactive Black 5 from Wastewater Using Bentonite Clay: Isotherms, Kinetics and Thermodynamics. Sustainability 2015, 7, 15302-15318. [CrossRef]

11. Sephton, M.G.; Webb, J.A. The role of secondary minerals in remediation of acid mine drainage by Portland cement. J. Hazard. Mater. 2019, 367, 267-276. [CrossRef] [PubMed]

12. Mamelkina, M.A.; Tuunila, R.; Sillanpaa, M.; Hakkinen, A. Systematic study on sulfate removal from mining waters by electrocoagulation. Sep. Purif. Technol. 2019, 216, 43-50. [CrossRef]

13. Aguiar, A.O.; Andrade, L.H.; Ricci, B.C.; Pires, W.L.; Miranda, G.A.; Amaral, M.C.S. Gold acid mine drainage treatment by membrane separation processes: An evaluation of the main operational conditions. Sep. Purif. Technol. 2016, 170, 360-369. [CrossRef]

14. Vital, B.; Bartacek, J.; Ortega-Bravo, J.C.; Jeison, D. Treatment of acid mine drainage by forward osmosis: Heavy metal rejection and reverse flux of draw solution constituents. Chem. Eng. J. 2018, 332, 85-91. [CrossRef]

15. Zouboulis, A.I.; Katsoyiannis, I.A. Recent Advances in Water and Wastewater Treatment with Emphasis in Membrane Treatment Operations. Water 2019, 11, 45. [CrossRef]

16. Bai, H.; Kang, Y.; Quan, H.E.; Han, Y.; Sun, J.; Feng, Y. Treatment of acid mine drainage by sulfate reducing bacteria with iron in bench scale runs. Bioresour. Technol. 2013, 128, 818-822. [CrossRef]

17. Yildiz, M.; Yilmaz, T.; Arzum, C.S.; Yurtsever, A.; Kaksonen, A.H.; Ucar, D. Sulfate reduction in acetate- and ethanol-fed bioreactors: Acidic mine drainage treatment and selective metal recovery. Miner. Eng. 2019, 133, 52-59. [CrossRef]

18. Dean, A.P.; Lynch, S.; Rowland, P.; Toft, B.D.; Pittman, J.K.; White, K.N. Natural Wetlands Are Efficient at Providing Long-Term Metal Remediation of Freshwater Systems Polluted by Acid Mine Drainage. Environ. Sci. Technol. 2013, 47, 12029-12036. [CrossRef]

19. Park, I.; Tabelin, C.B.; Jeon, S.; Li, X.L.; Seno, K.; Ito, M.; Hiroyoshi, N. A review of recent strategies for acid mine drainage prevention and mine tailings recycling. Chemosphere 2019, 219, 588-606. [CrossRef]

20. Jimenez-Castaneda, M.E.; Medina, D.I. Use of Surfactant-Modified Zeolites and Clays for the Removal of Heavy Metals from Water. Water 2017, 9, 235. [CrossRef]

21. Alakangas, L.; Andersson, E.; Mueller, S. Neutralization/prevention of acid rock drainage using mixtures of alkaline by-products and sulfidic mine wastes. Environ. Sci. Pollut. Res. 2013, 20, 7907-7916. [CrossRef] [PubMed]

22. Madzivire, G.; Maleka, P.P.; Vadapalli, V.R.K.; Gitari, W.M.; Lindsay, R.; Petrik, L.F. Fate of the naturally occurring radioactive materials during treatment of acid mine drainage with coal fly ash and aluminium hydroxide. J. Environ. Manag. 2014, 133, 12-17. [CrossRef] [PubMed]

23. Wigniewska, M.; Chibowski, S.; Urban, T.; Terpilowski, K. Investigations of chromium(III) oxide removal from the aqueous suspension using the mixed flocculant composed of anionic and cationic polyacrylamides. J. Hazard. Mater. 2019, 368, 378-385. [CrossRef] [PubMed]

24. Das, S.; Patra, P.; Singha, K.; Biswas, P.; Sarkar, S.; Pal, S. Graft copolymeric flocculant using functionalized starch towards treatment of blast furnace effluent. Int. J. Biol. Macromol. 2019, 125, 35-40. [CrossRef] [PubMed]

25. Sephton, M.G.; Webb, J.A.; McKnight, S. Applications of Portland cement blended with fly ash and acid mine drainage treatment sludge to control acid mine drainage generation from waste rocks. Appl. Geochem. 2019, 103, 1-14. [CrossRef] 
26. Name, T.; Sheridan, C. Remediation of acid mine drainage using metallurgical slags. Miner. Eng. 2014, 64, 15-22. [CrossRef]

27. Badescu, I.S.; Bulgariu, D.; Ahmad, I.; Bulgariu, L. Valorisation possibilities of exhausted biosorbents loaded with metal ions-A review. J. Environ. Manag. 2018, 224, 288-297. [CrossRef]

28. Deng, G.R.; Ma, J.C.; Zhang, X.P.; Zhang, Q.F.; Xiao, Y.Q.; Ma, Q.L.; Wang, S.B. Magnetic natural composite Fe3O4-chitosan@bentonite for removal of heavy metals from acid mine drainage. J. Colloid Interface Sci. 2019, 538, 132-141.

29. Jun, B.M.; Kim, Y.; Han, J.; Yoon, Y.; Kim, J.; Park, C.M. Preparation of Activated Biochar-Supported Magnetite Composite for Adsorption of Polychlorinated Phenols from Aqueous Solutions. Water 2019, 11, 1899. [CrossRef]

30. Yang, Y.; Wu, A.X.; Klein, B.; Wang, H.J. Effect of primary flocculant type on a two-step flocculation process on iron ore fine tailings under alkaline environment. Miner. Eng. 2019, 132, 14-21. [CrossRef]

31. Goldani, E.; Moro, C.C.; Maia, S.M. A Study Employing Differents Clays for Fe and Mn Removal in the Treatment of Acid Mine Drainage. Water Air Soil Pollut. 2013, 224, 1401. [CrossRef]

32. Farsi, A.; Javid, N.; Malakootian, M. Investigation of adsorption efficiency of $\mathrm{Cu} 2+$ and $\mathrm{Zn} 2+$ by red soil and activated bentonite from acid copper mine drainage. Desalin. Water Treat. 2019, 144, 172-184. [CrossRef]

33. Orakwue, E.O.; Asokbunyarat, V.; Rene, E.R.; Lens, P.N.L.; Annachhatre, A. Adsorption of Iron(II) from Acid Mine Drainage Contaminated Groundwater Using Coal Fly Ash, Coal Bottom Ash, and Bentonite Clay. Water Air Soil Pollut. 2016, 227, 74. [CrossRef]

34. Tsai, T.T.; Kao, C.M.; Wang, J.Y. Remediation of TCE-contaminated groundwater using acid/BOF slag enhanced chemical oxidation. Chemosphere 2011, 83, 687-692. [CrossRef] [PubMed]

35. Molahid, V.L.M.; Kusin, F.M.; Madzin, Z. Role of multiple substrates (spent mushroom compost, ochre, steel slag, andlimestone) in passive remediation of metal-containing acid mine drainage. Environ. Technol. 2019, 40, 1323-1336. [CrossRef]

36. Reddy, K.R.; Gopakumar, A.; Chetri, J.K. Critical review of applications of iron and steel slags for carbon sequestration and environmental remediation. Rev. Environ. Sci. Bio Technol. 2019, 18, 127-152. [CrossRef]

37. Wu, X.; Leung, D.Y.C. Optimization of biodiesel production from camelina oil using orthogonal experiment. Appl. Energy 2011, 88, 3615-3624. [CrossRef]

38. Guo, J.K.; Zhang, Y.T.; Che, S.Q. Performance analysis and experimental study on rainfall water purification with an extensive green roof matrix layer in Shanghai, China. Water Sci. Technol. 2018, 77, 670-681. [CrossRef]

39. Cao, L.; Shen, W.G.; Huang, J.Q.; Yang, Y.; Zhang, D.; Huang, X.Q.; Lv, Z.J.; Ji, X.L. Process to utilize crushed steel slag in cement industry directly: Multi-phased clinker sintering technology. J. Clean. Prod. 2019, 217, 520-529. [CrossRef]

40. Barisic, I.; Markovic, B.; Zagvozda, M. Freeze-thaw resistance assessment of cement-bound steel slag aggregate for pavement structures. Int. J. Pavement Eng. 2019, 20, 448-457. [CrossRef]

41. Dimitrova, S.V.; Mehandgiev, D.R. Lead removal from aqueous solutions by granulated blast-furnace slag. Water Res. 1998, 32, 3289-3292. [CrossRef]

42. Ishwarya, G.; Singh, B.; Deshwal, S.; Bhattacharyya, S.K. Effect of sodium carbonate/sodium silicate activator on the rheology, geopolymerization and strength of fly ash/slag geopolymer pastes. Cem. Concr. Comp. 2019, 97, 226-238.

43. Martinez, L.R.; Escalante, G.J.I. Alkali activated composite binders of waste silica soda lime glass and blast furnace slag: Strength as a function of the composition. Constr. Build. Mater. 2016, 119, 119-129. [CrossRef]

44. Gil, A.; Amiri, M.J.; Abedi-Koupai, J.; Eslamian, S. Adsorption/reduction of $\mathrm{Hg}$ (II) and $\mathrm{Pb}$ (II) from aqueous solutions by using bone ash/nZVI composite: Effects of aging time, Fe loading quantity and co-existing ions. Environ. Sci. Pollut. Res. 2018, 25, 2814-2829. [CrossRef] [PubMed]

45. Guo, Y.; Cui, X.L.; Li, Y.G.; Zhang, Q.H.; Wang, H.Z. The Effect of Aging Time on the Properties of Mg-Al-CO3 Layered Double Hydroxides and Its Application as a Catalyst Support for TiO2. J. Nanosci. Nanotechnol. 2016, 16, 5653-5661. [CrossRef] [PubMed]

46. Chang, Q.; Zhu, L.H.; Luo, Z.H.; Lei, M.; Zhang, S.C.; Tang, H.Q. Sono-assisted preparation of magnetic magnesium-aluminum layered double hydroxides and their application for removing fluoride. Ultrason. Sonochem. 2011, 18, 553-561. [CrossRef] [PubMed]

47. Hu, J.; Chen, G.H.; Lo, I.M.C. Removal and recovery of $\mathrm{Cr}(\mathrm{VI})$ from wastewater by maghemite nanoparticles. Water Res. 2005, 39, 4528-4536. [CrossRef] 
48. Liu, Z.M.; Li, X.; Xu, L.C.; Liu, R.R. A novel combined process of MFPAC coagulation and mineralized refuse adsorption for landfill leachate pretreatment. Desalin. Water Treat. 2017, 80, 74-82. [CrossRef]

49. Moon, D.H.; Wazne, M.; Cheong, K.H.; Chang, Y.Y.; Baek, K.; Ok, Y.S.; Park, J.H. Stabilization of As-, Pb-, and $\mathrm{Cu}$-contaminated soil using calcined oyster shells and steel slag. Environ. Sci. Pollut. Res. 2015, 22, 11162-11169. [CrossRef]

50. Magagane, N.; Masindi, V.; Ramakokovhu, M.M.; Shongwe, M.B.; Muedi, K.L. Facile thermal activation of non-reactive cryptocrystalline magnesite and its application on the treatment of acid mine drainage. J. Environ. Manage. 2019, 236, 499-509. [CrossRef]

51. Wang, Y.; Tang, X.W.; Chen, Y.M.; Zhan, L.T.; Li, Z.Z.; Tang, Q. Adsorption behavior and mechanism of Cd(II) on loess soil from China. J. Hazard. Mater. 2009, 172, 30-37. [CrossRef] [PubMed]

52. Meng, B.; Guo, Q.X.; Men, X.P.; Ren, S.Y.; Jin, W.L.; Shen, B.J. Preparation of modified bentonite by polyhedral oligomeric silsesquioxane and sodium dodecyl sulfate in aqueous phase and its adsorption property. Mater. Lett. 2019, 253, 71-73. [CrossRef]

53. Ma, J.Z.; Khan, M.A.; Xia, M.Z.; Fu, C.L.; Zhu, S.D.; Chu, Y.T.; Lei, W.; Wang, F.Y. Effective adsorption of heavy metal ions by sodium lignosulfonate reformed montmorillonite. Int. J. Biol. Macromol. 2019, 138, 188-197. [CrossRef] [PubMed]

(C) 2019 by the authors. Licensee MDPI, Basel, Switzerland. This article is an open access article distributed under the terms and conditions of the Creative Commons Attribution (CC BY) license (http://creativecommons.org/licenses/by/4.0/). 